\title{
Lenna Lowe Yost, temperance, and the ratification of the woman suffrage amendment by West Virginia
}

\author{
Karina G. Thurston \\ West Virginia University
}

Follow this and additional works at: https://researchrepository.wvu.edu/etd

\section{Recommended Citation}

Thurston, Karina G., "Lenna Lowe Yost, temperance, and the ratification of the woman suffrage amendment by West Virginia" (2009). Graduate Theses, Dissertations, and Problem Reports. 695.

https://researchrepository.wvu.edu/etd/695

This Thesis is protected by copyright and/or related rights. It has been brought to you by the The Research Repository @ WVU with permission from the rights-holder(s). You are free to use this Thesis in any way that is permitted by the copyright and related rights legislation that applies to your use. For other uses you must obtain permission from the rights-holder(s) directly, unless additional rights are indicated by a Creative Commons license in the record and/ or on the work itself. This Thesis has been accepted for inclusion in WVU Graduate Theses, Dissertations, and Problem Reports collection by an authorized administrator of The Research Repository @ WVU. For more information, please contact researchrepository@mail.wvu.edu. 
Lenna Lowe Yost, Temperance, and the Ratification of the Woman Suffrage Amendment by West Virginia

Karina G. Thurston

Thesis submitted to the

College of Arts and Sciences

at West Virginia University

in partial fulfillment of requirements

for the degree of

Master of Arts

in

History

Kenneth Fones-Wolf, Ph.D., Chair

Elizabeth Fones-Wolf, Ph.D.

Barbara Howe, Ph.D.

Department of History

Morgantown, West Virginia

2009

Keywords: Lenna Lowe Yost; suffrage; prohibition; temperance; Ellis A. Yost; women in West Virginia

Copyright 2009 Karina G. Thurston 


\section{ABSTRACT \\ Lenna Lowe Yost, Temperance, and the Ratification of the Woman Suffrage Amendment by West Virginia}

\section{Karina G. Thurston}

This thesis is a biography of West Virginia native Lenna Lowe Yost and her role in two important reform causes -- temperance and woman suffrage. It explores Yost's life and political accomplishments in both regional and national venues, progressing from her childhood, through her early activism, and culminating with the passage of the national woman suffrage amendment. During the Progressive Era, as Yost reached the apex of her career as an indispensable state leader, she had to navigate between divisions in the suffrage movement as well as local conflicts between prohibitionists and suffragists. In these movements Lenna Yost proved herself to be a skilled organizer and influential reformer, whose fight for the betterment of women's and children's lives opened the door for women nationally to become politically active. This study strives to place Yost's work in West Virginia in a national context, similar to the efforts of women in more progressive states of the era. 


\section{Acknowledgments}

The choice to pursue a graduate education involves a great deal of commitment, dedication and discipline from the student. However, without the help and support of numerous professors, advisors, friends and families, the successful completion of a master's degree program would be impossible.

I wish to thank my committee chair, Dr. Kenneth Fones-Wolf, for introducing me to this topic, for his support, and for his encouragement throughout my graduate journey at the West Virginia University. Without his patience, constructive criticism, and guidance I would not have finished my thesis. I also wish to thank the members of my graduate committee, Dr. Elizabeth Fones-Wolf and Dr. Barbara Howe, for their insightful comments and for supporting me on this project.

A special gratitude to Dr. Steve Zdatny for welcoming me to the graduate history program, and Dr. Shannon Frystak, for being a wonderful teacher and for helping me improve my writing when I first started my graduate journey. I would also like to thank Dr. Joseph Hodge for being an outstanding graduate advisor.

I also wish to thank the staff, librarians, and archivists at the West Virginia and Regional Collection for allowing me to examine Lenna Lowe Yost's papers, for taking the time to answer all my questions, and for always being welcoming. I am most grateful to Kevin Fredette, for his encouragement and guidance at the West Virginia and Regional Collection.

I especially want to thank my friends at the West Virginia University, Joshua Esposito and William Feeney, for taking the time to read my drafts and offer valuable advice, and for encouraging me when I did not believe I could finish this 
project. I would also like to thank Shannon Tinnell, Jinny Turman-Deal, William Hal Gorby, and all the students from the history department, for their support and for providing a much-needed distraction at social gatherings. Thank you to my dear friends Simi Islam and Jamie Sacchetti for welcoming me to their homes while I was working on the final steps of my thesis, making my stay in Morgantown more enjoyable.

I extend a special gratitude to Jared Thurston. I also wish to thank my family, for all their love and support. Finally, to my mom, Dulce Helena Rittner, for her encouragement, for investing in my education, believing in me, and trusting in my potential throughout the more difficult times of my academic career. Without her guidance and love I could not have completed this thesis. 


\section{Table of Contents}

Abstract.......................................................................................................ii

Acknowledgments ................................................................................................ iii

Chapters:

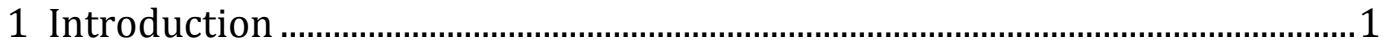

2 "A Life in Politics"

3 “Temperance and Suffrage: The Women's

Suffrage Movement and the 1916 State

Referendum Campaign in West Virginia" .................................................................. 33

4 "Lenna Lowe Yost and the Ratification

of the Federal Woman Suffrage Amendment

in West Virginia." ......................................................................................................... 60

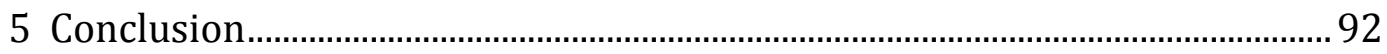

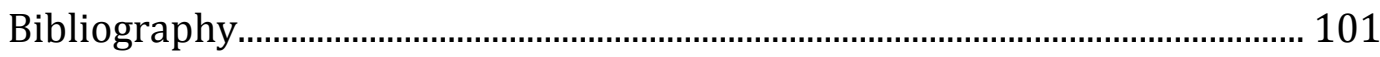




\section{Chapter 1: Introduction}

As the United States reached its centennial, it celebrated a hundred years of incredible growth in land and wealth. It had expanded from a small grouping of thirteen colonies to a country that spanned a continent. While a number of predominantly white males profited greatly during this period, others, especially women, children, immigrants and African Americans, lacked a full voice in their government, languished in poor working settings, and survived in near poverty conditions. Therefore, some Americans started drifting away from the principles of laissez faire; calling, instead, for a more dynamic government, able to deal with the problems that immigration, industrialization and urbanization had brought. As a result, distinct social and political movements emerged at the end of nineteenth century, giving birth to a new era, the Progressive Era. Reformers of the Progressive Era aimed primarily at dealing with the consequences of expansion, concentrated wealth, and corruption. Labor laws, women's rights, temperance, and women suffrage were some of the programs that reformers championed in that era. Transitioning from the domestic sphere into the public sphere, women fought for and led the majority of these movements. Refusing to accept that they had no voice and eager to shape their society, they rose up in organized groups and demanded basic rights; ones that they felt were promised to all human beings at the country's inception over a hundred years before. ${ }^{1}$

\footnotetext{
${ }^{1}$ Noralee Frankel and Nancy S. Dye, Gender, Class, Race and Reform in the Progressive Era (Lexington, Kentucky: The University Press of Kentucky, 1991), 1.
} 
Among those leaders was Lenna Lowe Yost, who struggled for and led two of the era's most notable social programs, woman suffrage and temperance, and in the process helped revolutionize the role of women in the political realm. In 1934, when referring to the great accomplishments American women had made in the past decades, the Washington Post acknowledged the little known West Virginia native: "Among these leaders is Lenna Lowe Yost (Mrs. Ellis A. Yost), who it is generally conceded, has more contacts and wider acquaintance with men and women of national prominence than any other person in the country." ${ }^{2}$

This thesis will examine the life and contributions of reformer Lenna Lowe Yost to the women's movement in the United States and West Virginia. Historian Ann Effland wrote a detailed and wonderful account of the woman suffrage movement in West Virginia. However, new papers were made available to the West Virginia and Regional Collection after Effland had completed her work. These new papers, added to the Lenna Lowe Yost manuscript collection, which will be cited as "ADD" in this project, help us understand the specific contributions of Lenna Lowe Yost to the woman suffrage battle and other progressive reform movements in West Virginia. In addition, new literature on the woman's movement in the United States has been made available since Effland completed her master's thesis. This project will explore how Yost operated politically, her strategies in West Virginia, and how she compared with other reformers in the national arena during the Progressive Era. I will explore her life, tactics, arguments and political views regarding several reform efforts, particularly women suffrage and temperance, placing her as a

\footnotetext{
2 The Washington Post, 1934, Lenna Lowe Yost Papers, Box 1, West Virginia and Regional History Collection, West Virginia University, Morgantown, WV (hereafter, Yost Papers)
} 
prominent leader in women's rights in the local and national spectrums. Finally, this thesis will explore the bond between the temperance and the woman suffrage movements in the United States and particularly, its impact on the woman suffrage movement in West Virginia.

Since the tension between the suffrage campaign and the liquor interests was evident in West Virginia, the connection between temperance and suffrage makes Lenna Yost particularly interesting. Indeed, some feared that her connection to the temperance issue hurt early efforts to ratify a woman suffrage amendment in her state. Yost, however, was not alone in confronting these problems. Scholarship on the woman suffrage movement explores women's earlier involvement with the Women's Christian Temperance Union (WCTU) and its subsequent connection with other important reform movements, particularly the suffrage cause. Not only did many members of the National American Woman Suffrage Association (NAWSA) belong to the WCTU, many came to the suffrage movement through their prior experience with the temperance cause. Despite the difficulty of leading both the temperance and woman suffrage campaigns in West Virginia, however, Yost eventually successfully navigated the state's ratification of the federal woman suffrage amendment.

Lenna Lowe Yost was a native of Barnettsville, Marion County, West Virginia. She married Ellis Yost, a young lawyer, in 1899. The Yosts became active in politics and progressive reform causes. ${ }^{3}$ Both Lenna and Ellis Yost belonged to the Methodist Episcopal Church and were devoted Republicans. Ellis Yost successfully

\footnotetext{
3 “Lenna Lowe Yost (Mrs. Ellis A. Yost), West Virginia Political and Government Leader," (undated typescript), Yost Papers, Box 3.
} 
ran for the West Virginia legislature in 1909 and 1913. One of Ellis Yost's most significant achievements in the state's legislature was the passage of a prohibition law, or House Bill Number 8, in 1913, popularly known as the Yost Law. ${ }^{4}$ Meanwhile, Lenna Yost joined the West Virginia chapter of the WCTU, and in 1908, only a few short years after joining the WCTU, she became the president of the West Virginia branch, and remained in charge of the chapter until 1918. As president of the WCTU, Lenna Yost revolutionized the organization's tactics, contributing to the final victory of the temperance cause in her state. ${ }^{5}$ In the temperance crusade, the Yosts found a common bond. Moreover, experience in prohibition reform boosted Lenna Lowe Yost's future passion for reform and involvement in politics.

Lenna Yost's experience with the temperance movement alerted her to the importance of woman suffrage. Unable to vote, Yost, like many women reformers of her time, was often unable to effectively pressure lawmakers to pass legislative actions she believed essential for the nation's progress. Therefore, while president of the WCTU, in 1916, Yost also took over the presidency of the West Virginia Equal Suffrage Association (WVESA), a division of NAWSA. That same year, as head of both organizations, Yost started a state referendum campaign for the suffrage amendment while continuing to fight for the enforcement of prohibition laws in West Virginia. Later, in 1919, while serving as Chairman of the Ratification Committee of the WVESA, Yost helped her state ratify the federal woman suffrage amendment.

\footnotetext{
${ }^{4}$ Medora Mason Wolfe, “Ellis Asby Yost,” March 1959, Yost Papers, Box 3.

${ }^{5}$ Mrs. Ned Johnson, (ed), Mountaineer Memories, (undated typescript),12.
} 
A familiar theme that runs through the scholarship of women's history is the division within the woman's movement. Women of the Progressive Era often found themselves divided when dealing with distinct women's rights issues. They had complex agendas and did not always collaborate with one another. Different ideologies, ethnicity, and race set them apart in the many causes for which they fought. They possessed different strategies and distinct approaches on the suffrage battle, temperance cause, and protective legislation for women, among other reforms.

In their fight for the ballot, women differed in tactics and approaches, allowing for rivalry to emerge between the distinctive suffrage groups. For example, although suffragist Alice Paul, founder of the National Woman's Party (NWP). was a strong asset to the struggle for a national women's suffrage amendment, NAWSA considered Paul a radical feminist, and condemned her militant strategies. ${ }^{6}$ Was Yost as radical as Alice Paul or did she use a more educational approach like the one Carrie Chapman Catt proposed through NAWSA? This thesis will place Yost as an influential reformer, exploring her tactics among the variety of suffrage organizations, which were crucial for the victory of the suffrage cause in West Virginia. By examining the primary sources available, I will also show that, throughout the crucial years of 1919 and 1920, she corresponded regularly with prominent politicians and citizens of West Virginia on the matter of woman suffrage and, most importantly, on the ratification of the federal woman suffrage amendment, also known as the Susan B. Anthony amendment. Although Yost did not

\footnotetext{
${ }^{6}$ Nancy F. Cott, The Grounding of Modern Feminism (New Haven and London: Yale University Press, 1987), 54.
} 
pen memoirs or write her version of the history of the woman suffrage movement in West Virginia, she left behind many letters between herself and influential reformers of the time, such as Carrie Chapman Catt, as well as the West Virginia governor at the time, John J. Cornwell. ${ }^{7}$

Upon successfully aiding her state's ratification of the nineteenth amendment, Yost moved into the political arena, establishing herself as a capable reformer in the areas of education and as an asset to the Republican Party. Moreover, Yost remained an active correspondent for the Union Signal, the WCTU journal, writing articles on temperance and other issues while simultaneously continuing to participate in politics within West Virginia and always struggling to improve conditions for women in the state.

This project will follow a chronological sequence starting with Lenna Lowe Yost's early life and influences, ending with her contribution to the final stages of the battle for the ballot and the political causes she joined after suffrage was won. The second chapter will explore her life, her marriage, and her initial involvement with the temperance cause. In the third chapter, her role in the West Virginia suffrage referendum in 1916, and her involvement with the prohibition movement will come into play. In the fourth chapter, I will explore her extraordinary efforts, which led to final victory of the women suffrage movement in West Virginia. Finally, chapter five will highlight her participation in other political reforms, and her achievements within the Republican Party, women's organizations, and government agencies

\footnotetext{
${ }^{7}$ Sarah Baldwin, "Lenna Lowe Yost Archives Chronicle the Woman Suffrage Movement in State and Nation,” West Virginia and Regional Collection Newsletter, Volume 19, No. 1, 2003, West Virginia and Regional Collection, West Virginia University, Morgantown, WV.
} 
during the 1920s and 1930s, which earned her a spot among the leading reformers of her state. 


\title{
Chapter 2: Starting a Life in Politics, 1878- 1915
}

\begin{abstract}
What do I want out of life? Well, that is rather a large order. Not large because I want so much, but large because the range of possibilities is too vast for definition. ${ }^{1}$
\end{abstract}

Lenna Lowe Yost

The range of possibilities was indeed large for Lenna Lowe Yost. Her extraordinary achievements are evident not only in her work as a member of the Republican Party, but also in her life. From an early age, Yost took advantage of the opportunities that were presented to her. Her relatives paid special attention to her academic capabilities and invested in her studies, which paid dividends. Her accomplishments throughout her life were significant. After receiving her education, Lenna Lowe Yost moved into the public sphere to start her work as a reformer in the areas of temperance, suffrage, education, and women's and children rights. Like many women of her time, her involvement in the temperance movement in the United States allowed Yost to enter politics and acquire the necessary influence to make a difference in other reforms of the Progressive Era and throughout her entire political career. This chapter will explore the prohibition movement in the United States and West Virginia, Lenna Yost's early personal life, her political background, and earlier career as a temperance advocate.

Lenna Lowe was born on January 25, 1878, in Basnettville, Marion County, West Virginia. Basnettville (today known as Basnett) is a small village about a half a

\footnotetext{
1 “What I Want out of Life,” Lenna Lowe Yost Papers, Box 3, West Virginia and Regional History Collection, West Virginia University, Morgantown, WV (hereafter, Yost Papers)
} 
mile from Fairview, West Virginia. ${ }^{2}$ The village of Basnettville was named after Lenna Lowe's maternal great-grandfather, Samuel B. Basnett; her father, Jonathan S. Lowe, was a Justice of Peace in Basnettville. He passed away when Lenna Lowe was only eight years old, leaving Columbia Basnett Lowe, Lenna's mother, with four children (Fred, Earle, Glen, and Lenna) to raise. In order to support her children, Columbia Basnett Lowe owned a hat shop in Fairview. ${ }^{3}$

Fairview, which was laid out in 1845, is close to Fairmont, West Virginia (about eleven miles northwest). Farming and agricultural related industries prevailed in Fairview until 1890. However, in the 1890s, oil well drilling boomed in the town, contributing to a population boom. "Around 1900 the nights in Fairview were picturesque as well as extremely rowdy with the oil workers and others coming into town." Bowling alleys and a horseracing track also entertained the town then, and sports such as baseball, basketball, and football, were of great interest to Fairview's citizens. ${ }^{4}$

During her younger years in Marion County, Lenna Lowe was an organist at the St. John's Methodist Episcopal Church in Fairview (built in 1823), the oldest church in Fairview. ${ }^{5}$ She remained a member of the Methodist Episcopal Church throughout her life. In her earlier years, Lenna Lowe attended school in Fairview. Among the subjects she studied were "arithmetic, reading, spelling, grammar,

\footnotetext{
${ }^{2}$ Geo A. Dunnington, History and Progress of the County of Marion, West Virginia, 1880, (Fairmont, West Virginia: George A. Dunnington, Publisher, 1992), 75.

3 "Lenna Lowe Yost (Mrs. Ellis A. Yost), West Virginia Political and Government Leader, Distinguished in civic, educational, temperance, suffrage and social welfare programs,” Yost Papers, Box 3.

${ }^{4}$ Marion County Historical Society (W.Va.), A History of Marion County, West Virginia, 1985 (Fairmont, W.Va.: Marion Historical Society, 1986), 47.

${ }^{5}$ Marion County Historical Society, A History of Marion County, 84.
} 
physiology, geography, U.S. History and writing." ${ }^{6}$ During her high school years, Lenna Lowe moved to Delphi, Indiana, and lived with relatives. She then studied art at the Ohio State University and later graduated from the West Virginia Wesleyan College in Buckhannon.

In the late nineteenth century a new world of civic engagement was opening up for college educated women, leading them to reform activities, such as labor unions, settlement houses, and temperance organizations. Social changes in the aftermath of the Civil War were the catalyst for many of these opportunities. This first generation of college educated women, including Florence Kelley, Jane Addams, and Harriot Stanton Blatch, found themselves incapable of using their degrees to find traditional careers. Unable to vote and discriminated against because of their gender, women had to find a way to have their voices heard. For example, Kelley became highly involved with women and child labor reforms, Jane Addams initiated the settlement house movement, while Blatch revolutionized the suffrage movement, as well as women's role in politics. According to Kelley, college educated, middle- class women should use their knowledge for the benefit of those in need. ${ }^{7}$ Addams and Kelley, among other prominent figures of their time, became inspirations to later generations of women, such as Lenna Lowe, especially in the Progressive Era, when reformers were criticizing the principles of laissez faire, calling instead for a more active government.

\footnotetext{
${ }^{6}$ Marion County Historical Society, A History of Marion County, 16.

${ }^{7}$ Kathryn Kish Sklar, Florence Kelley \& the Nation's Work, The Rise of Women's Political Culture, 18301900 (New Haven and London: Yale University Press, 1995), 5
} 
As a result of pioneers like Kelley and Addams, Lenna Lowe had more options at the turn of the century. Opportunities in professional areas and in university education, in fields such as medicine and law, were gradually increasing for women during Lenna Lowe's college years. ${ }^{8}$ Like Kelley and Blatch, after receiving her education, Lenna Lowe sought to engage in civic reforms, such as the temperance movement, in order to acquire influence in politics, and fight for other causes. While studying at Wesleyan College, Lenna Lowe met Ellis Asby Yost, whom she married on September 26, $1899 .{ }^{9}$ Her husband's political career, as well as her early involvement and subsequent leadership in the prohibition movement in West Virginia, provided her with influence and power to advance her career in politics.

Ellis Yost was born in Fairview on December 12, 1872. After working in the merchandise business for six years, in 1895, Ellis Yost became the mayor of Fairview. He subsequently enrolled at several institutions, including the Wilmington Conference Academy, Ohio Northern University, and Ohio Wesleyan University. Ellis Yost's brother, Fielding Yost, had a distinctive career himself. Fielding "Hurry Up" Yost played football for West Virginia University and later achieved fame as the football coach and athletic director at the University of Michigan, positions he held from 1901 until 1946.10

Initially, after their marriage, Lenna and Ellis Yost lived in Fairview. In 1900, the Yosts moved to Clarksburg, West Virginia, and Ellis got a job in the real estate

\footnotetext{
${ }^{8}$ Ellen Carol DuBois and Lynn Dumenil, Through Women's Eyes, An American History with Documents (Boston and New York: Bedford/ ST. Martin's, 2005), 409.

9 "Lenna Lowe Yost (Mrs. Ellis A. Yost), West Virginia Political and Government Leader," Yost Papers, Box 3.

10 "Fielding Yost, another son of Marion County, excelled with Wolverines," http://www.dailymail.com/Sports/200712180207.
} 
and insurance businesses. In 1902 their only son, Leland Yost, was born. ${ }^{11}$ According to several people who personally knew Lenna and Ellis Yost, their marriage was one of great trust and joy. According to a later reminiscent, "this marriage has merited the word 'ideal' as few can do. Over an exceptionally happy sixty years, this devoted couple has never failed in daily communication though often separated by great distance." 12 Throughout her career, Lenna Yost traveled to many places to fulfill her responsibilities as temperance and suffrage advocate, or proponent of education and the betterment of conditions for children and women.

The distance from her husband, however, did not keep the Yosts from maintaining a close relationship with each other. Ellis Yost wrote several poems to his wife throughout their marriage:

"My Love and I:"

Twenty years ago to- day, my love We joined our hearts as one And thru the years since that hour We've kept the faith begun

The joy and bliss I've known my dear

With you my lovely queen Is sweeter far than tongue can tell

As we've walked in love serene

To me you've been a precious boon

A help- mate always true

So sweetly understanding

Your husband thru and thru

Better far than precious gold Our rubies of priceless worth

\footnotetext{
${ }^{11}$ Josh W. Kirk, Progressive West Virginians (Wheeling, WV: Wheeling Intelligencer, 1923), 237.

12 "Lenna Lowe Yost (Mrs. Ellis A. Yost), West Virginia Political and Government Leader,” Yost Papers, Box 3.
} 
Has been the sweetness of your soul

That's made a heaven on earth

So constant you have always been

So sweet, so pure, so bright

To talk with you in love's own way

Has been my heart's delight

We'll journey on together dear

In hope and faith and love

Sharing our joys and burdens

Til we reach our home above

Ellis A. Yost

September 26, 191913

In 1905 the Yosts moved to Morgantown, West Virginia, where, with his wife's support, Ellis Yost continued his studies by enrolling in the law program at West Virginia University. During his time at WVU, Ellis Yost became president of the Young Men's Christian Association and a member of the Literary Society and the debating team. Moreover, Yost became the head of the Mountain, an honorary society. ${ }^{14}$

In Morgantown, the Yosts became active in politics and Progressive Era reform causes, particularly the temperance crusade. Shortly after graduating from WVU in 1908, Ellis Yost successfully ran for the state legislature in 1909 and again in 1913, representing Monongalia County. There, he started his legislative battle for prohibition in West Virginia. Although there is no record of exactly what inspired Ellis to get involved with the prohibition cause in his state in the beginning of the twentieth century, there are clues. He, like his religious and frugal parents, was also

\footnotetext{
${ }^{13}$ Ellis A. Yost, “My Love and I,” 26 September, 1919, Yost Papers, Box 3.

${ }^{14}$ Medora Mason Wolfe, “Ellis Asby Yost,” March 1959, Yost Papers, Box 3.
} 
a member of the Methodist Episcopal Church, which advocated temperance. ${ }^{15}$ Therefore, religion might have played a role.

Meanwhile, Lenna Lowe Yost started working for the temperance cause as well. Upon joining the West Virginia chapter of the Woman's Christian Temperance Union (WCTU), she became involved with the temperance movement early in her political career and worked relentlessly for the "dry" cause. Ellis and Lenna Yost not only shared a domestic life but also political and social ideals; both of the Yosts were ardent Republicans. Ellis Yost fully supported his wife's career and her political accomplishments in West Virginia and around the nation. According to Anne Steese Richardson's sketch of Lenna Yost, Ellis Yost's "political interests have always been shared by his wife, and he has given every consideration to her public career." 16 As Ellis Yost became active politically, the temperance cause united the Yosts, and together, they fought for prohibition in their state.

From the beginning, the prohibition movement in West Virginia and in the United States generated diverse opinions, and it remained controversial throughout its existence. With the rise of industrialization, urbanization, immigration, and increasing agitation from religious groups, the nation experienced a growing wave towards the temperance movement in the 1890s, essentially ushering in the Progressive Era. This led to the formation of local branches of groups and organizations, such as the Anti- Saloon League in 1896, the Prohibition Party, and the WCTU. The WCTU, founded in 1874 in Ohio, was one of the most important

\footnotetext{
${ }^{15}$ Medora Mason Wolfe, “Ellis Asby Yost,” March 1959, Yost Papers, Box 3.

${ }^{16}$ Anna Steese Richardson, "Personality Scketch,” 1928, Yost Papers, Box 3.
} 
women's organizations ever assembled. ${ }^{17}$ Ultimately, the hard work of local reformers, such as the Yosts, and lawmakers led to the passage of state prohibition laws and the eighteenth amendment, prohibiting the sale and manufacturing of alcohol in the United States. ${ }^{18}$

Since its first appearance, before the Civil War, the temperance movement in the United States had been trying to slow down the alcoholism problem in the country. Alcohol use was extensive and thought necessary by many to get them through a day of hard labor. It was also used for medicinal purposes, making it easily accessible in pharmacies. Alcoholic beverages were thought to be more sterile than other beverages such as water and milk, and, therefore, many individuals sometimes made it the beverage of choice. However, by the end of the nineteenth century, the number of saloons and alcohol related problems had multiplied, and people from all over the country joined forces in order to protect their homes. Since males constituted the majority of those frequenting saloons, women were most likely to be the recipients of the repercussions stemming from spousal alcohol abuse. Mrs. Emma Fagan gave the following statement to the Clarksburg Daily Telegram, "I was married in 1889 and in the twenty-six years of my married life I never saw my husband sober."19 Therefore, many women reformers had their interests deeply entrenched in the temperance crusade.

The prohibition movement had a long history in West Virginia. Temperance organizations were already prominent in western Virginia even before West

\footnotetext{
${ }^{17}$ DuBois and Dumenil, Through Women's Eyes, 299.

${ }^{18}$ Thomas R. Pegram, Battling Demon Rum, The Struggle for a Dry America, 1800- 1933 (Chicago, Illinois: Ivan R. Dee, 1998), 85.

19 “Hubby Drunk Quarter Century, Declares Wife,” The Clarksburg Daily Telegram, 8 November 1916
} 
Virginia acquired its statehood. On April 20, 1830, local citizens had organized the Monongalia Temperance Society. ${ }^{20}$ Waitman T. Willey, who eventually became one of the first senators of the newly formed state of West Virginia, was among the influential leaders of the Sons of Temperance, between 1848 and the Civil War. As their leader, Willey organized conferences and speeches in order to further the temperance cause. ${ }^{21}$ Moreover, the growing interest in temperance that western Virginia counties had displayed by the 1850s, inspired the Grand Division of the Sons of Temperance to hold its third quarterly session in Morgantown. In 1852, the Broad Run Baptist Association "adopted a resolution asking the Virginia legislature to prohibit the manufacture and sale of intoxicating liquor."22

After West Virginia became a state, the question of prohibiting the sale and manufacture of alcohol and license fees became a subject of discussion among the new members of the legislature. Although "West Virginia from its beginning followed a system of licensing and waged a fight against the evils resulting from intemperance," lawmakers wanted to pass concrete prohibition laws. Temperance radicals advocated for a prohibition clause to be included in the state's constitution. Others, such as delegate Peter Van Winkle, believed that simply persuading an individual not to drink was more effective. The result was a new compromising clause stating, "Laws may be passed regulating or prohibiting the sale of intoxicating liquors within the limits of the state." 23 This early concern with prohibition laws in

\footnotetext{
${ }^{20}$ E. Kidd Lockard, “The Temperance Movement in West Virginia,” (MA Thesis, West Virginia University, 1937), 4.

${ }^{21}$ Lockard, "The Temperance Movement in West Virginia,” 5.

${ }^{22}$ Lockard, “The Temperance Movement_in West Virginia,”, 6.

${ }^{23}$ Lockard, “The Temperance Movement in West Virginia,” 11.
} 
West Virginia paved the way for future, stricter laws in the state during the Progressive Era.

As the prohibition movement entered the twentieth century, it experienced a shift in ideology. The ultimate goal of Progressive Era reformers was to make American society more efficient and moral. Reformers as a whole "gave vigorous support to two great crusades: one to preserve democracy at home and the other to make the world safer for democracy."24 There was a social awakening in which reformers saw the need to fight the problems that industrialization, immigration and urbanization had brought upon their nation. Yet, some progressives were more concerned with Americanizing the immigrants and controlling blacks, for they believed in the morals of the puritan way of life and the principles of white supremacy.

At the end of the nineteenth century it was clear that America was facing some challenging issues. According to temperance advocates, from a social perspective, alcohol facilitated these problems because it hindered one's ability to think clearly. Disease, crime, vices, and prostitution were damaging the nation's progress. As corruption and decaying living conditions increased in the cities, reformers agreed on the need for change and the need for keeping the principles of democracy strong. However, agreeing on what exactly was wrong with American society and what American democracy meant represented a challenge in uniting Americans towards a common goal in the Progressive Era. For example, if one believed excessive drinking to be a social problem as opposed to an individual's

\footnotetext{
${ }^{24}$ James H. Timberlake, Prohibition and the Progressive Movement 1900- 1920 (Cambridge, Massachusetts: Harvard University Press, 1963), 1.
} 
failure, then it was the government's responsibility to deal with the temperance issue, hence the support for laws that addressed the drinking problems in the nation. Although some supporters of temperance advocated for moderation and personal responsibility, others were radical in their views and aimed, with the help of their government, at eliminating the sale and manufacture of alcohol completely. ${ }^{25}$

Supporters of a prohibition amendment at the time included the economists. According to Simon N. Patten, one of the founders of the American Economic Association, prohibition was necessary and essential for the survival of the United States. Sobriety among the population contributed to the nation's prosperity for it helped "outcompete" other countries that allowed its citizens to drink. ${ }^{26}$ Other economists, such as Irving Fisher, believed in the "doctrines and methods of postmillennialist evangelical Protestantism," which emphasized the need for strict personal discipline to generate financial prosperity. ${ }^{27}$ To Fisher, Americans should work towards being moral in order to boost progress, also believing the government should act as the agent and facilitator of progress, hence the need for the passage of a prohibition amendment.

Temperance advocates accentuated the inefficiency of workers who were impaired by the effects of alcohol. Consequently, they asserted that alcohol interfered with the nation's progress and the principles of democracy reformers were trying to spread. Economically speaking, prohibition could bring fortune and

\footnotetext{
${ }^{25}$ Mrs. Ned Johnson (ed), Mountaineer Memories, 1883- 1983, (undated typescirpt), 2.

${ }^{26}$ Mark Thornton, The Economics of Prohibition (Salt Lake City: University of Utah Press, 1991), 12.

${ }^{27}$ Thornton, The Economics of Prohibition, 16.
} 
prosperity to the United States. "The gospel of temperance promised that if a man could just control his impulses, subdue his appetites, and redirect his energies, his family might survive and even prosper thorough economic shifts." ${ }^{28}$ Like other reformers of the Progressive Era, prohibitionists envisioned an efficient, clean, and modern American society.

As America experienced a religious revival at the end of the nineteenth century, the spiritual aspect of prohibition also became a strong element within the temperance movement. This evangelical revival helped Protestants in America "create a new respect for life that promoted a number of humanitarian reforms," including the temperance movement. ${ }^{29}$ Many Protestant ministers encouraged the members of their churches to engage in social reforms in order to bring men to Christ. This type of reform was known as the Social Gospel and it eventually became a main focus of orthodox American Protestantism. Protestants were convinced that the liquor industry was a selfish and irresponsible institution, which promoted immorality and greed among men and women, contradicting with the teachings of Jesus. Since many people considered drinking a vice, they felt that it damaged one's body and soul, causing unrest and conflict among people, separating men from God.

The rise of the Anti- Saloon League and the WCTU also coincided with the religious wave that was sweeping the country. These organizations became important allies against the evils of liquor. From its inception, through speeches, the WCTU's long-time president, Frances Willard, made it clear that "the organization

\footnotetext{
${ }^{28}$ DuBois and Dumenil, Through Women's Eyes, 214.

${ }^{29}$ Timberlake, Prohibition and the Progressive Movement, 14
} 
would have a deeply religious tone and spirit." ${ }^{30}$ She often called for the members of WCTU to engage in fasting and prayer. Willard made religion the focal point of the WCTU's temperance crusade throughout her presidency and "inspired WCTU members with the certainty that theirs was a religious mission and that God called them to save their homes, families, and nation by creating a more just and equitable world."31 Despite the influence religion had on various organizations, however, women reformers often encountered obstacles in regards to the role religion and the Bible played in their lives, especially in the social arena. Suffragists "could point out those parts of the Scriptures that seemed to favor the equality of the sexes,"32 or radically denounce the Bible, as Elizabeth Cady Stanton did. ${ }^{33}$

The Prohibition Movement was also part of a middle-class reform. The temperance cause allowed white middle-class women to move into the public sphere, where they fought for social, religious, and political reforms. ${ }^{34}$ Moreover, immigration, especially from Ireland, and the movement of black labor from the South to the North after the Civil War, increased the servant labor market, allowing northern urban women more spare time to concentrate their work on volunteer reform organizations. Even though urban women had received some education, their opportunities in the work force were scarce when compared to those of their male counterparts. The WCTU provided a venue where white women could be in

\footnotetext{
${ }^{30}$ Carolyn De Swarte Gifford and Amy R. Slagell, Let Something Good be said, Speeches and Writing of Frances E. Willard (Urbana and Chicago: University of Illinois Press, 2007),11

${ }^{31}$ Gifford and Slagell, Let Something Good be said, xxviii.

${ }^{32}$ Aileen S. Kraditor, The Ideas of the Woman Suffrage Movement, 1890- 1920 (New York and London: W.W. Norton \& Company, 1981), 76.

${ }^{33}$ Kraditor, The Ideas of the Woman Suffrage Movement, 77.

${ }^{34}$ Timberlake, Prohibition and the Progressive Movement, 30.
} 
control, hold prestigious positions, engage in social reform, and participate in the political arena.

Drinking was also closely intertwined with politics. For example, "of the 1,002 political meetings held in New York City on the local level in 1886, nearly 800 were held in saloons." ${ }^{35}$ Politicians had their financial interests deeply entrenched in the liquor business, for their relationship with immigrants and saloon owners aided their political campaigns and helped them win votes. This relationship between the liquor industry and politics generated corruption, which, in turn, encouraged reformers of the Progressive Era to fight for political democracy.

The temperance crusade was varied in its strategies and accomplishments throughout the nation. In West Virginia, in particular, it achieved great success early and Ellis and Lenna Yost's contributions made a significant difference. As a member of the West Virginia legislature, Ellis fought for prohibition laws in his state; Lenna, as president of the West Virginia WCTU from 1908 through 1919, influenced the movement with innovative strategies and approaches at a time when women did not possess a voice in their government.

As president of her state's WCTU, religion played an important role on Lenna Yost's political choices. Lenna Yost maintained the religious tone Willard had set for the organization and fully embraced religious arguments as a crucial reason to support temperance. The West Virginia WCTU always started meetings with prayers. In one of her presidential addresses, Yost stated, "I earnestly recommend that we do all within our power to encourage the reading and study of the Bible in

\footnotetext{
${ }^{35}$ Ruth Bordin, Woman And Temperance, The Quest for Power and Liberty, 1873- 1900 (New Brunswick, London: Rutgers University Press, 1981), 6
} 
the public schools." 36 The West Virginia WCTU pledge of alliance to the temperance movement was, "I hereby solemnly Promise, God helping me, to abstain from all distilled, fermented and malt liquors, including wine, beer and cider, and to employ all proper means to discourage the use of, and traffic of the same." 37 Being a member of the Methodist church throughout her life, Lenna Yost followed the teachings of the Social Gospel, believing it to be her duty, as a Christian, to work for reforms that made America more morally grounded.

The economic arguments for prohibition were also part of Lenna Yost's agenda. Yost believed that the money wasted on the liquor traffic and consumption, should be used to further important causes and other needed reforms. In one of her addresses as the WCTU president in West Virginia, she stated, "White Ribboners have chosen to devote themselves largely to the one work of destroying the liquor traffic, believing that its abolition will be clearing the way for a thousand reforms with which society and the government are confronted."38

Lenna Lowe Yost understood the economic implications of abolishing the liquor traffic in the country, particularly in her own state. In one of her addresses as president of the West Virginia WCTU, she stated, "The general prosperity in the states which have adopted prohibition is most encouraging." Yost added, "Statements of actual conditions made by those in authority are convincing, and

\footnotetext{
36 West Virginia Woman's Christian Temperance Union, Twenty- Eighth Year, Charleston, October 5, 6, 7, 1910, Minutes of the Convention and executive Committee, Reports of Corresponding Secretary, Treasurer, Superintendents and Organizers, and a List of Unions and Officers, (Fairmont, West Virginia: Index Print, 1910), 24, West Virginia and Regional Collection, West Virginia University, Morgantown, WV.

${ }^{37}$ WCTU pledge, 30 April, 1908, Harvey Harmer papers, Box 3, West Virginia and Regional History Collection, West Virginia University, Morgantown, WV (hereafter, Harmer papers)

${ }^{38}$ Mrs. Ned Johnson, Mountaineer Memories, 14.
} 
ought to forever silence the hackneyed cry 'Prohibition kills business'"39 In another speech, Yost also reported that "Evidence of the economic value of prohibition obtained by the fifty- sixth and Market streets building and Loan Association has been made public by Harry A Mackey, chairman of the state workmen's compensation board." As Yost pointed out, Mackey stated, "At a recent meeting of this association, a saloonkeeper brought in as new members ten men, each of whom put up $\$ 10$ to buy shares. Not one of these men had ever saved anything before." 40 Lenna Yost was hopeful that Americans would understand the long-term benefits, both financially and socially, of total prohibition to the nation. She proudly stated, "At last the moral consciousness of the nation is revolting against the great economic waste, and against the waste of human souls." 41

Although Jennie Smith and Frances Willard had organized the first local WCTU chapter in West Virginia in 1883, Lenna Yost took over the presidency of the state's organization in 1908 and remained in charge throughout the more challenging years of the prohibition movement. Not only was she in charge when the state passed its prohibition amendment, she was also the state's WCTU president when West Virginia ratified the federal prohibition amendment six years later. Her

\footnotetext{
39 West Virginia Woman's Christian Temperance Union, Twenty- Eighth Year, Charleston, October 5, 6, 7, 1910, Minutes of the Convention and executive Committee, Reports of Corresponding Secretary, Treasurer, Superintendents and Organizers, and a List of Unions and Officers, (Fairmont, West Virginia: Index Print, 1910), 13, West Virginia and Regional Collection, West Virginia University, Morgantown, WV.

${ }^{40}$ Lenna Lowe Yost, "Prohibition Saves Money,” The Union Signal, 3 June, 1920, Yost papers, ADD Box 1.

41 West Virginia Woman's Christian Temperance Union, Twenty- Eighth Year, Charleston, October 5, 6, 7, 1910, Minutes of the Convention and executive Committee, Reports of Corresponding Secretary, Treasurer, Superintendents and Organizers, and a List of Unions and Officers, (Fairmont, West Virginia: Index Print, 1910), 13, West Virginia and Regional Collection, West Virginia University, Morgantown, WV.
} 
vision targeted the movement from all angles. From educating children at an early age to utilizing the media as a tool, she broadened the public's understanding of temperance. Her capacity to delegate and her understanding for the need of as many smaller branches of the WCTU as possible, directed prohibition advocates in West Virginia towards the right direction. Moreover, her organizational abilities as well as her understanding of politics were responsible for her success as the leader of the temperance movement in West Virginia.

In 1908, under Lenna Lowe Yost's leadership, there was a membership gain of 1,000 members and the formation of 54 new unions. ${ }^{42}$ In 1909, the WCTU announced the organization of thirty new White Ribbon unions in West Virginia. A year later, "Mrs. Yost announced in her address that 37 of 55 counties are now prohibition counties." Although the WCTU already had local branches operating in several counties, in 1910, Yost recommended that the number of local WCTU organizations be multiplied, and that the ones who were already in action be strengthened. That same year, the organization's accomplishments included "62 speech contests, 643 bushels of fruits and vegetables to needy, 537 visits to public institutions, 6,348 floral gifts distributed and 97,228 pages of literature distributed. 43

Lenna Yost also emphasized the need for the early education of children and teachers in public schools on temperance related issues, which aimed "to place total abstinence for future generations upon the basis of intelligence rather than mere

\footnotetext{
${ }^{42}$ Mrs. Ned Johnson, Mountaineer Memories, 10

${ }^{43}$ Mrs. Ned Johnson, Mountaineer Memories, 12.
} 
prejudice." 44 According to her, educators should be aware of the evils and the scientific implications resulting from alcohol use, hence the call for the continued distribution of books such as the Gulick Hygiene series, and Sir Victor Horseley's "Alcohol in the Human body" to public school teachers. She also supported scientists when they attempted to connect deadly diseases, such as tuberculosis, to alcohol use. As Yost reported, "The international congress in the study of tuberculosis passed a resolution strongly emphasizing the importance of combining the fight against tuberculosis with the fight against alcohol." 45 Like other prohibitionists then, she understood that religion alone was not enough to recruit supporters to the temperance cause. Concrete evidence of the physical damages liquor caused was crucial for the final victory.

Among her strategies to encourage alcohol abuse education, she recommended the organization of medal contests, organization of music clubs, and the distribution of prizes for essays. She also urged that the WCTU "organize the children into Loyal Temperance Legions, let the children march with banners whose inscriptions shall tell the truths; hold rallies; sow the State knee deep in literatureliterature that will expose the falsehoods in regard to reverse effects of prohibition upon business, so broadly circulated by the salon element." Educating the children

\footnotetext{
44 West Virginia Woman's Christian Temperance Union, Twenty- Eighth Year, Grafton, West VA., October 6, 7, 8, 1909, Minutes of the Convention and Executive Committee, Reports of Corresponding Secretary, Treasurer, Superintendents and Organizers, and a List of Unions and Officers, (Fairmont, West Virginia: Index Print, 1910), 27, West Virginia and Regional Collection, West Virginia University, Morgantown, WV.

45 West Virginia Woman's Christian Temperance Union, Twenty- Eighth Year, Charleston, October 5, 6, 7, 1910, Minutes of the Convention and executive Committee, Reports of Corresponding Secretary, Treasurer, Superintendents and Organizers, and a List of Unions and Officers, (Fairmont, West Virginia: Index Print, 1910), 17, West Virginia and Regional Collection, West Virginia University, Morgantown, WV.
} 
within the Loyal Temperance Legion assured that new generations were disciplined and recruited to the prohibition cause. ${ }^{46}$

The conversion of the public sentiment against the saloons seemed to be of great importance to Yost. Moreover, she seemed fully aware of the role that the media played in influencing public opinion. In her 1910 presidential address, she ordered "that a great literature and press campaign be launched" on prohibition issues. ${ }^{47}$ "Strong temperance articles in prominent magazines and periodicals are exerting a tremendous educating influence, she asserted." 48 Yost also organized meetings in her state with both the Prohibition Party and the Anti- Saloon League. These meetings proved to be beneficial, for they united the proponents of prohibition in an organized manner, generating efficiency within the movement.

Lenna Lowe Yost was among the radical prohibitionists who were "committed to both total abstinence and prohibition." Reports in the WCTU record book in 1911 when Yost was still its president, show the organization's full support for "total abstinence as the only safe line of personal conduct with regard to strong drink, narcotics and harmful drugs." Yost and the WCTU called for the state's Board

\footnotetext{
46 West Virginia Woman's Christian Temperance Union, Twenty- Eighth Year, Grafton, West VA., October 6, 7, 8, 1909, Minutes of the Convention and Executive Committee, Reports of Corresponding Secretary, Treasurer, Superintendents and Organizers, and a List of Unions and Officers, (Fairmont, West Virginia: Index Print, 1910), 27, West Virginia and Regional Collection, West Virginia University, Morgantown, WV.

47 West Virginia Woman's Christian Temperance Union, Twenty- Eighth Year, Charleston, October 5, 6, 7, 1910, Minutes of the Convention and executive Committee, Reports of Corresponding Secretary, Treasurer, Superintendents and Organizers, and a List of Unions and Officers, (Fairmont, West Virginia: Index Print, 1910), 24, West Virginia and Regional Collection, West Virginia University, Morgantown, WV.

48 West Virginia Woman's Christian Temperance Union, Twenty- Eighth Year, Charleston, October 5, 6, 7, 1910, Minutes of the Convention and executive Committee, Reports of Corresponding Secretary, Treasurer, Superintendents and Organizers, and a List of Unions and Officers, (Fairmont, West Virginia: Index Print, 1910), 12, West Virginia and Regional Collection, West Virginia University, Morgantown, WV.
} 
of Education not to employ teachers who smoked. Also in 1911, the WCTU convention delegates made it clear they would not rest until prohibition was fully achieved in West Virginia. "We shall teach Prohibition, preach Prohibition, pray for Prohibition, and work for Prohibition, from now until West Virginia is dry." 49 Yost's radicalism and determination helped generate the pressure necessary to persuade lawmakers and West Virginia's citizens to embrace the need for stricter prohibition laws. She educated herself on the multiple aspects of temperance and its benefits to progress, allowing her to make a plausible case for prohibition based on religious, scientific, economic, and political reasons.

As leader of the West Virginia's WCTU at the time, Lenna Lowe Yost supported her husband's efforts to turn West Virginia into a "dry" state. In 1912, as a member of the West Virginia legislature, Ellis Yost proposed what came to be called the "Yost Law," which outlawed alcohol. Throughout Ellis Yost's political campaign for a prohibition amendment in West Virginia, Lenna Yost gathered the necessary support and influence to aid her husband's attempts for a "dry" West Virginia. By that time, she had already been president of the WCTU for five years, and the hard work she had put into the organization prepared the ground for the her husband's prohibition law battle in the legislature.

Throughout that year of 1912, she organized prayer meetings and parades through the WCTU. ${ }^{50}$ Also in the campaign of 1912, the WCTU organized children into a "Young Campaigners Band." Lenna Yost had proposed earlier in 1910, as one of her strategies, that the WCTU held contests at local schools for papers describing

\footnotetext{
${ }^{49}$ Mrs. Ned Johnson, Mountaineer Memories, 13.

${ }^{50}$ Mrs. Ned Johnson, Mountaineer Memories, 14.
} 
the benefits of prohibition. Moreover, "two new county organizations were formed, 50 new local unions and a total membership gain of well over 700." Under Lenna Yost's leadership, "West Virginia was seventh in the nation in her membership increase" in 1912. Members of the WCTU held up their banners and worked close to the polls teaching voters how to vote yes for the amendment on the ballot. On June 12, 1912, the West Virginia WCTU called for a "Universal Day of Prayer for success of the Prohibition Amendment,"51 referring to the "Yost law."

After years of fighting for stricter prohibition laws in their state, Ellis and Lenna Yost witnessed the success of their hard work and combined efforts. The Yost prohibition act, was ratified in West Virginia on February 11, 1913, by a majority of 92,342, and went into effect on July 1,1914.52 At midnight of June 30,1914, all the state's saloons were required to close their doors. The amendment, which was considered the strictest prohibition law in the United States, "made the manufacture, sale, or giving away of intoxicating liquors anywhere within the state illegal." 53 It also did not permit newspapers that advertised the use of alcohol or any other sort of alcohol advertisement to be sold in the state. ${ }^{54}$ West Virginia became a "dry" state as a result.

To better implement the Yost Law, the state assigned tax commissioners to different counties who were responsible for making sure that the local businesses and authorities were enforcing the law. On June 22, 1915 Fred O. Blue, one of the state's commissioners, received a letter from Herman Guy Kump, a prosecuting

\footnotetext{
${ }^{51}$ Mrs. Ned Johnson, Mountaineer Memories, 13

${ }^{52}$ West Virginia Acts of the Legislature, thirty first regular session, 1913, 96.

53 Lockard, "The Temperance Movement in West Virginia, 40.

54 "Prohibition," www.wvculture.org/HiStory/government/prohibition02.html.
} 
attorney, who would later become a West Virginia senator, requesting his help with liquor trafficking in Weaver. "For sometime I have been expecting you to send me a man here to round up two or three illicit liquor traffickers." ${ }^{55}$ According to historian E. Kidd Lockard, "The "Yost law" was strengthened by each legislative meeting before 1931, with the exception of the session held in 1925." 56 For example, in 1923, the Yost law was broadened "so that alcoholic preparations, such as hair tonics, might be regulated. ${ }^{57}$ According to Woman Suffrage and Politics, "No state campaign ever quite so completely rallied the 'drunks' and 'ne'ers do wells' of all kinds of [sic] Election Day as did West Virginia." 58

Like many reformers of the Progressive Era, Lenna Lowe Yost also believed that ridding the nation from the alcoholism problem opened up opportunities for reforms in other areas. Under her presidency, the WCTU in West Virginia fought for a more efficient American society. As Yost stated in 1913, when the state prohibition amendment passed in West Virginia, "This evil not only hinders the progress of many needed reforms, but it is largely responsible for the conditions that make the great humanitarian movements." ${ }^{59}$ From speeches Yost gave throughout her involvement with the temperance movement, one can observe the many propositions she believed essential to aid in the nation's progress.

For example, in Morgantown, West Virginia, the local chapter of the state's WCTU included in their meetings their concern for "Americanizing" immigrants. In

\footnotetext{
${ }^{55}$ Kump to Blue, 22 June, 1915, Herman Guy Kump Papers, Box 12, West Virginia and Regional History Collection, West Virginia University, Morgantown, WV (hereafter, Kump Papers).

${ }^{56}$ Lockard, "The Temperance Movement in West Virginia," 40

${ }^{57}$ Lockard, "The Temperance Movement in West Virginia," 41

${ }^{58}$ Carrie Chapman Catt and Nettie Rogers Shuler, Women Suffrage And Politics, The Inner Story Of The Suffrage Movement (Seatlle and London: University of Washington Press, 1923), 302

${ }^{59}$ Mrs. Ned Johnson, Mountaineer Memories, 14.
} 
one of the Morgantown's WCTU's meetings, Mrs. F.F Bridge gave an informative talk on the immigration problem and, therefore, encouraged WCTU members to also work towards teaching the American way to foreigners. Immigrants, as the town's WCTU record stated, "compared their manner of living here and in their home lands, of their urgent efforts to become american-ized, of how they were hampered with lack of knowledge of our ways and customs urged upon us personal interest in their welfare helping them to a better understanding of what it means to be thoroughly Americanized." 60 Later, while writing for the Union Signal, Yost made some of the WCTU's goals and expectations known as well, including "bills to enforce War time Prohibition, Americanization, peyote, and other measures the WCTU has sponsored await consideration by next Congress." ${ }^{11}$ Lenna Yost's support for party politics, education, and prison reform in West Virginia, which will be explored later, places her among the progressives who envisioned a better America. Being concerned with women's and children's rights drove Yost to reevaluate the meaning of American democracy, just as other reformers of the Progressive Era had done.

Economic, social, geographical, religious, and political motives were responsible for the success of the "dry" cause and its subsequent failure in West Virginia, and in the nation as well. Some temperance reformers, such as Lenna Yost, embraced the progressive movement and actually viewed temperance as an aid to progress towards moral ideals, political education, and democracy. A sober nation meant a safer home, and, consequently, the betterment of women's and children's

\footnotetext{
${ }^{60}$ Mrs. A.K Miller and Mrs. Urle Ridgway, Woman's Christian Temperance Union records, 6 March, 1918, Morgantown Woman's Christian Temperance Union (WV) collection, West Virginia and Regional Collection, West Virginia University, Morgantown, WV.

${ }^{61}$ Lenna Lowe Yost, “The Union Signal,” 13 March, 1919, Yost Papers, ADD Box 1.
} 
lives at home and in the public arena. Child education and political education were top priorities on Lenna Yost's agenda as a reformer of the Progressive Era, and I will explore these topics later.

Women, despite lacking the vote, had an indirect but important effect on political issues, particularly the temperance cause. Women reformers, like Yost, were very much involved in pressuring the government for the passage of legislative measures, including prohibition laws in their state. ${ }^{62}$ They made important political decisions such as choosing between maintaining their support for a political party or supporting important controversial issues, such as suffrage and temperance.

When Frances Willard became the president of the WCTU in 1879, she envisioned an organization that fought for a variety of reforms, such as education, ending child labor, betterment of prison conditions, and woman suffrage. Willard, who sometimes was accused of being a socialist, introduced more radical views into the WCTU's agenda and viewed women's participation in politics through the ballot as an essential factor in the protection of women's rights. ${ }^{63}$ Willard was always concerned with the women's movement as a whole and "envisioned the WCTU as a training place for women reformers, providing them with opportunities to acquire the self- confidence and skills needed to become activist." ${ }^{64}$ Some even suggested that the WCTU was not a priority in Willard's agenda and that she used the organization to gain influence and fight for other important women issues, such as

\footnotetext{
${ }^{62}$ Rebecca Edwards, Angels in the Machinery, Gender in American Party Politics from the Civil War to the Progressive Era (New York: Oxford University Press, 1997), 39

${ }^{63}$ Joe L. Coker, Liquor Cause in the Land of the Lost Cause, Southern White Evangelicals And The Prohibition Movement (Kentucky: The University Press of Kentucky, 2007), 215.

${ }^{64}$ Gifford and Slagell, Let Something Good Be Said, xxviii.
} 
suffrage. Other members of WCTU, including its first president, Annie Wittenmyer, condemned women suffrage, stating, "asking women to campaign for the vote, would strike a 'fatal blow at home."' 65 The Alabama Christian Advocate also made clear the tensions between the temperance and suffrage movement in the South. Initially, the paper supported the WCTU; however, the growing ties with the suffrage movement proved to be an unwanted factor. "When they allowed a few such women as old Sister Cady Stanton and her sort to put into the movement woman suffrage, they put the thing beyond our reach," stated the editors. ${ }^{66}$

With the passage of the "Yost law," the WCTU continued its support for the prohibition amendment and helped keep West Virginia on the "dry" side of the country even before 1919, when the eighteenth amendment was ratified. The temperance crusade in West Virginia not only united the Yosts, but it also provided a venue for Lenna Lowe Yost's political activism. During her husband's time as member of the legislature and, as leader of the prohibition amendment, Lenna Yost became acquainted with politicians and influential members of society. The ties she established at that time proved to be crucial as Lenna Yost advanced in other areas of reform, such as suffrage, and expanded her political career within the Republican Party. Lenna Yost fully embraced Willard's views and, without hesitation, took the many opportunities that came her way in the various areas of government, maintaining her principles and working relentlessly towards using politics as her primary tool as she fought for the reforms she believed in.

\footnotetext{
${ }^{65}$ Bordin, Women and Temperance, 46.

${ }^{66}$ Coker, Liquor Cause in the Land of the Lost Cause, 203.
} 


\section{Chapter 3: Temperance and Suffrage: The Women's Suffrage Movement and the 1916 State Referendum Campaign in West Virginia}

Many women reformers and temperance advocates of the Progressive Era hoped for legislative actions that would bring progress to their nation and protect them from the evils of alcoholism. Unable to vote, they formed unions, neighborhood associations, organized strikes, joined organizations, and fought for women's and children's reforms. Despite achieving partial victories as the result of their extraordinary efforts, women possessed little power over most areas of politics, business, and social reforms without the support of men. ${ }^{1}$ As women dove deeper into the reforms they thought essential to humanity, they realized that, without the vote, their fight was sometimes irrelevant and it often resulted in failure. While men could use their voting power to elect politicians that would support their causes, women did not possess that privilege. ${ }^{2}$ Unable to more effectively influence politicians and lawmakers, many women placed increasing importance on the right to vote and, therefore, began lending more support to the suffrage movement.

Experience in temperance activism in West Virginia alerted Lenna Lowe Yost to other reforms of the Progressive Era, especially the importance of obtaining the right to vote. As Yost advanced in the public and political settings, she became part of a group of activists, such as Frances Willard, who fought and believed in both temperance and woman suffrage, as well as a number of other reforms. According to

\footnotetext{
${ }^{1}$ Carolyn De Swarte Gifford and Amy R. Slagell, Let Something Good be said, Speeches and Writing of Frances E. Willard (Urbana and Chicago: University of Illinois Press, 2007), xxxi.

${ }^{2}$ Aileen S. Kraditor, The Ideas of the Woman Suffrage Movement, 1890- 19020 (New York and London: W.W. Norton \& Company, 1981), 219.
} 
Frances Willard, "'everything is not in the temperance reform but the temperance reform should be in everything,' and 'The White Ribbon includes all reform; whatever touches humanity touches us.'”3 As historian Genevieve McBride points out, "A subtle but more significant impact of the crusade," referring to the temperance struggle, "was an impetus for women to organize, ostensibly for temperance but inevitably for the ballot." ${ }^{4}$ Through the temperance movement, women reformers established themselves in the public arena.

Already president of the West Virginia Woman’s Christian Temperance Union (WCTU), in 1916 Lenna Yost took over the presidency of the West Virginia Equal Suffrage Association (WVESA), a division of the National American Woman Suffrage Association (NAWSA). This was the "first occasion for the presidencies of these two powerful organizations," the WCTU and NAWSA, "to coincide in any state." ${ }^{5}$ As head of both organizations in West Virginia, Yost aided her state’s referendum campaign for a woman suffrage amendment, while continuing to fight for the enforcement and strengthening of the state's prohibition laws she had helped pass. As she had done for the prohibition cause, in a decisive time for the woman suffrage cause, Yost rose to leadership and took charge of the movement in her state. At a time when the United States was undergoing profound political and social changes, Lenna Lowe Yost led two of the biggest reform causes in West Virginia, temperance and women suffrage. However, the connection between suffrage and temperance proved to be a complex one and it generated a mixed outcome, particularly in West Virginia.

\footnotetext{
${ }^{3}$ Gifford and Slagell, Let Something Good be said, xxxvi.

${ }^{4}$ Genevieve G McBride, On Wisconsin Women, Working for Their Rights from Settlement to Suffrage (Madison, Wisconsin: The University of Wisconsin Press, 1993), 99.

5 Anne W. Effland, “The Woman Suffrage Movement in West Virginia, 1867-1920” (MA Thesis, West Virginia University, 1983), 49
} 
The creation of a woman suffrage organization in the United States can be traced back to the efforts of Elizabeth Cady Stanton, Susan B. Anthony, Henry Blackwell, and Lucy Stone through the National Woman Suffrage Association (NWSA) and the American Woman Suffrage Association (AWSA). Division within the women's rights movement is a theme that runs through the scholarship on woman suffrage. In 1869, women reformers witnessed a split in the movement due to ideological differences, mainly concerning the passage of the Fourteenth and Fifteenth amendments after the Civil War. Lucy Stone formed the AWSA, while Susan B. Anthony and Elizabeth Cady Stanton founded the NWSA. It would not be until 1890 that the two organizations united to form NAWSA. ${ }^{6}$ Later, as the fight for the vote intensified in the early twentieth century, women experienced a split in the suffrage movement once more. Like the suffragists before them, Carrie Chapman Catt and Alice Paul led two strong opposing organizations in the Progressive Era, NAWSA and the National Woman's Party (NWP) in the fight for suffrage throughout the late 1910s.

Both NAWSA and the NWP established organizations in West Virginia. However, mirroring the rest of the nation, the woman suffrage movement in West Virginia progressed slowly, particularly at the end of the nineteenth century. According to historian Anne Effland, West Virginia "was a state whose movement began late and progressed slowly, yet it was one whose support of woman suffrage seemed almost taken for granted." ${ }^{7}$ While some western states had already passed a state suffrage amendment by the early 1900s, others had unsuccessfully submitted state referenda and suffrage

\footnotetext{
${ }^{6}$ Marjorie Spruill Wheeler, One Woman, One Vote, Rediscovering the Woman Suffrage Movement (Troutdale, Oregon: New Sage Press, 1995), 12.

${ }^{7}$ Effland, "The Woman Suffrage Movement in West Virginia," 2.
} 
amendment proposals to their state legislatures. In West Virginia, it was not until 1916 that the state legislature considered a state referendum for woman suffrage.

Social and political changes in the United States influenced suffragists' thoughts and strategies throughout their journey. Historian Aileen Kraditor states, “earlier period suffragists had based their demand for political equality with men on the same ground as that on which their men had based their demand for political equality with their English rulers two generations before.” ${ }^{8}$ Initially, women’s rights advocates, such as Elizabeth Cady Stanton and Susan B. Anthony, were demanding the vote based on the fact that, as United States citizens, they had the right to vote. Furthermore, with the passage of the fifteenth amendment after the Civil War, Anthony and Stanton attempted, unsuccessfully, to justify their voting based on their citizenship rights. Unable to win the vote based solely on these arguments, suffragists changed their strategy during the Progressive Era.

In the Progressive Era, the need for social reform was connected to the need for the vote, "hence the claim to equality for women could not rest upon an abstract assertion of equality; it required concrete demands for specific social and political rights.” Women shifted from demanding the vote based solely on their natural born right to highlighting the unique service and ability they could provide their government. This change in the philosophy of the suffrage movement throughout the Progressive Era was strong and evident. As many women were calling upon the government to intervene in several social and political reforms, the suffrage cause questioned the norms of the era. Many women were relying on exposing their biological differences with men as a strategy in order to obtain the vote. With the mission to “clean up” politics, women

\footnotetext{
${ }^{8}$ Kraditor, The Ideas of the Woman Suffrage Movement, 44.

${ }^{9}$ Kraditor, The Ideas of the Woman Suffrage Movement, 48.
} 
argued that they could bring experience and a distinct touch into the different areas of the political sectors, improving their government and aiding a national movement toward social progress. As the Clarksburg Telegram asserted, "when the powers for evil may secure the upper hand, and it may devolve upon the women, in such an emergency, to throw themselves into the breach and by their votes to save our country from destruction." ${ }^{10}$ J.S. Lakin, West Virginia Board of Control president, stated, "There are more good women than bad women and the good, clean, honest vote would be increased." 11 Judge James Damron, also from West Virginia, agreed that “if the good women of West Virginia had an opportunity to express themselves by a ballot, we would not only have better and efficient officers to conduct our state and local governments, but that the morals of the state would be placed upon a higher standard.”12

As this new strategy came into play in the Progressive Era, Lenna Lowe Yost was part of a generation of suffragists who added the expediency argument to the suffrage cause as well. Yost believed women had distinct skills and unique experiences, different from those of men, to offer their government, which would make the nation more efficient. As she pointed out, "women found time to extend their housekeeping activities to embrace entire towns. From interior decoration they progressed to beautifying the streets of their cities and villages and to developing parks and playgrounds."13 Moreover, just as women helped their husbands and sons at their homes, they could offer the same help to American politics. Yost displayed strong convictions in regards to the place women were to take in American politics. According to her, women should "enter

\footnotetext{
10 “Women Suffrage Very Ably Urged,” The Clarksburg Daily Telegram, 2 November 1916.

11 “For Suffrage is Jim Lakin,” The Clarksburg daily Telegram, 7 November 1916.

12 Damron to Yost, 3 November, 1919, Lenna Lowe Yost Papers, ADD Box 1, West Virginia and Regional History Collection, West Virginia University, Morgantown, WV. (hereafter, Yost Papers).

${ }^{13}$ Mrs. Yost Radio Address, “Women in Politics,” 22 September, 1932, Yost Papers, Box 3.
} 
politics with sane, clean ideals; to make the most of her responsibility in promoting good results through good government, and to cooperate with men and work shoulder to shoulder with them to the ultimate good of their mutual interests." 14 This argument helped Lenna Yost enter politics and gain the respect from men and women alike.

Like other women reformers of the Progressive Era, Lenna Yost seemed to embrace the biological differences that distinguished the way in which women would make their contributions to politics once they obtained the vote. According to Yost, women were "naturally constructive in temperament, endowed with a special faculty for economy in management and efficiency in getting results,” which were also "essential qualifications for success in politics as in homemaking;” Yost went further, "women are, by nature conservative. It is to their credit that they have progressed steadily, but sanely and wisely, in assuming their share in the responsibilities of the government." ${ }^{15}$ Many women reformers of the Progressive Era shared Yost’s view. In West Virginia, Yost expressed her convictions, offered leadership and introduced guidelines for the woman’s movement in her state.

By obtaining the vote, Lenna Lowe Yost was eager for collaboration between men and women in order to promote the necessary political education, legislative changes, and progress needed in any great democratic government. Yost was careful to assert that "The quality of leadership is the same way in either sex.” According to Yost, women were to “espouse” a political party and make it better, just as she does in the home. As Yost wrote, women “entered upon a serious study of government, --municipal,

\footnotetext{
${ }^{14}$ Mrs. Ellis A. Yost, "How Women Share in Government Responsibilities," (undated typescript), Yost Papers, Box 3.

${ }^{15}$ Mrs. Ellis A. Yost, "Republican Party Calls for Young Women,” (undated typescript), Yost Papers, Box 3.
} 
state and national, --with enthusiasm and determination; a program that has given us an army of well-informed and well-trained women who are giving valuable and valued service to the political Party they have espoused.”16

Already, Yost displayed a passion for party politics. Political education was her top priority, for she believed it to be the most effective way women turned their votes into action. Upon obtaining the vote, women, with their special skills and knowledge of politics, could aid their husbands and male politicians in creating a more efficient society. She was convinced of the absolute need to choose a political Party upon being able to vote, and thus called upon women to contribute their special skills to their Party of choice. "The foundation stones of a substantial Party structure are laid in the voting precinct; and it is woman's capacity for taking infinite pains in detail work of this character that is making her, today, a symbol of political efficiency and a potential Party leader," Yost asserted in one of her several speeches. ${ }^{17}$ By embracing the fact that women reformers were tied to greater efficiency, Lenna Yost supported a common theme that dominated the Progressive Era: women were to clean up politics and, consequently, political parties.

Once Lenna Yost assumed the presidency of the WVESA, she worked towards blending her own political convictions with those of the woman suffrage organization she chose to support. As a member of NAWSA, Yost's strategies in West Virginia mirrored those of the national association. In 1915, the West Virginia legislature submitted a woman suffrage amendment to the state to be decided by the voters in a state referendum. That year, NAWSA was still supporting a state-by-state approach in winning the vote.

\footnotetext{
${ }^{16}$ Mrs. Ellis A Yost , “An Interpretation of Politics,” (undated typescript), Yost Papers, Box 3.

${ }^{17}$ Lenna Lowe Yost, “Taking Politics Serious,” 11 May, 1934, Yost Papers, Box 3.
} 
The Parkersburg Sentinel reported, "The association by an overwhelming vote yesterday, decided to continue its present policy of working for equal rights through both national and state legislation.” ${ }^{18}$ As a result, Yost supported her state’s first and only suffrage referendum. By that time, NAWSA's rival, the NWP, formally known as the Congressional Union (CU), was already giving its full support to a constitutional amendment granting women the vote by pressuring politicians and recruiting fundraisers and suffragists to their cause.

In contrast to NAWSA, the NWP, which Alice Paul founded in 1916, had developed different approaches in order to achieve its goals. Paul was a radical feminist who used strategies such as picketing in the White House to "punish the party in power" for not supporting the suffrage amendment. When arrested, she grabbed the headlines by engaging in hunger strikes aimed at embarrassing her jailors. ${ }^{19}$ She also refused to subordinate her goals to party loyalty. Paul’s organizations, "worked during the 1914 congressional elections to defeat Democratic candidates in the equal-suffrage states. ${ }^{20}$ In 1916, Alice Paul also led a campaign against then Democratic candidate for president Woodrow Wilson, due to his lack of support for woman suffrage. By doing that, Paul and the NWP were not encouraging women to choose a political party, but to choose suffrage. When accused of partisanship, the NWP "explained that it was not pro-Republican or anti-Democrat; it was simply pro-suffrage.”21

NAWSA condemned this strategy of punishing the party in power and opted for a more educational and less confrontational route. According to The Parkersburg Sentinel,

\footnotetext{
18 “Woman Debate Campaign Plans,” The Parkersburg Sentinel, 7 September 1916.

${ }^{19}$ Nancy F. Cott, The Grounding of Modern Feminism (New Haven and London: Yale University Press, 1987), 54.

${ }^{20}$ Kraditor, The Ideas of the Woman Suffrage Movement, 234.

${ }^{21}$ Kraditor, The Ideas of the Woman Suffrage Movement, 237.
} 
"Virtually all the speakers," from NAWSA, "declared for strict neutrality in the presidential campaign and to continue the non- partisan efforts of the association to bring about equal suffrage throughout the United States.”22 The Parkersburg Sentinel also reported that NAWSA “defeated by an overwhelming vote a resolution that the association in the present national campaign, support only those candidates for national offices who pledge their support to the passage of the Susan B. Anthony amendment for a federal constitutional amendment."23

Following NAWSA's policy and her own partisan convictions, Yost opposed the NWP's strategy as well. According to The West Virginian, “Mrs Ellis A. Yost, chairman of the state campaign committee, announced that the West Virginia organization had no connection whatsoever with the Woman’s Party."24 The Parkersburg Sentinel also reported Yost's announcement, “Our organization, which is waging the battle for the adoption of the amendment to our state constitution, is composed of members of all parties." Yost continued, "We are receiving the support of members of all parties, and, even if it were not contrary to the policy of our organization it would be sheer folly to break the political neutrality of half a century." ${ }^{25}$ In a later speech, she made her political priorities clear: "1. Political education, 2. Party Organization, 3. Support of Republican candidates for office.,26

As an ardent Republican, Yost encouraged women to join the party. However, her major concern was with women choosing a party, even if it meant joining the Democratic

\footnotetext{
22 “Women Debate Campaign Plans,” The Parkersburg Sentinel, 7 September 1916.

23 "Women Refuse to Pledge Support,” The Parkersburg Sentinel, 8 September 1916.

24 “Equal Suffragists Are Real Neutrals, Have Friends in All Political Parties Says Mrs. Yost,” The West Virginian, 5 September 1916.

25 “Not Connected with Woman's Party, The Parkersburg Sentinel, 25 September 1916.

${ }^{26}$ Mrs. Ellis A. Yost, “Interpretation of Politics,” (undated typescript), Yost Papers, Box 3.
} 
Party. Establishing political goals for life was Yost’s most valuable advice to women. When asked about her political ideals, she responded, "Choose your ideal in politics and work toward it consistently and persistently."27 Any opportunity Yost had, she persuaded women to choose a party and work towards the goals within their organization of choice. In one of her speeches, she asserted, "I would like to persuade more women that they can make their most valuable contribution to the public welfare through active affiliation with a Political Party." ${ }^{28}$ Yost added, "I am not a feminist in the strictest sense of the word.” Emphasizing towards the need to work with the men upon joining an existing political party of their choice, Yost stated there was "no need for feminist movement."29

As the suffrage question gained noticeable ground in West Virginia in the 1910s, state senators and representatives started considering the possible ways in which they could best address the issue at hand. Allowing the voters to decide through a referendum approach represented a plausible solution for the members of the legislature on the suffrage question. West Virginia Senator H. G. Kump explained the reasoning behind the decision to allow voters to decide the suffrage controversy, "woman is after all a mystery, the great conundrum of the twentieth century, and if we cannot in this chamber solve this question, we can safely leave it to the wisdom, chivalry and manhood of West Virginia.”30

However, the referendum approach received support and criticism from both parties in West Virginia. At that time, Americans viewed the Democratic Party as an institution that lacked an innovative approach to fixing the problems in American society.

\footnotetext{
${ }^{27}$ Anna Steese Richardson, “Personality Sketch,” 1928, Yost Papers, Box 3.

${ }^{28}$ Lenna Lowe Yost, "What I am trying to do," (undated typescript), Yost Papers, Box 3.

${ }^{29}$ Lenna Lowe Yost, “American Woman,” (undated typescript), Yost Papers, Box 3.

${ }^{30}$ Effland, “The Woman Suffrage Movement in West Virginia,” 37.
} 
Therefore, Democrats looked to obtain support from progressives by endorsing the state referendum approach. ${ }^{31}$ Some West Virginia citizens however, were unhappy with this decision. In some parts of the state, "the report was actually negative, claiming the bill was 'designed to upset all the theories of government and the relations of the sexes as known since the dawn of human history.",32

Lenna Yost led the state referendum campaign for suffrage in West Virginia throughout 1916. As soon as she became the president of the WVESA, she started managing the campaign closely, bringing the headquarters to her own house. Yost also transferred the organization's literature department to Morgantown, which strengthened the campaign with congressional speeches on suffrage, posters, and personal appeals from citizens on the matter of suffrage. ${ }^{33}$ Under Yost's leadership, the WVESA campaign was intense and received full support from NAWSA. Suffragists distributed posters, bulletins and sent "flying squadrons" of speakers throughout the state to educate and recruit voters for the suffrage cause. Publicizing the cause through newspapers and bulletins also became an important weapon for the movement.

The WVESA encouraged the formation of new suffrage clubs throughout the state. Rural districts in West Virginia were important targets for the suffragists, who "were urged to make clear their anti-liquor stand, for that would be to their advantage in a dry state like West Virginia.”34 Yost also requested, "Every magisterial district and voting precinct in your county should be in charge of a chairman who will be responsible for all activities in that territory." She urged, "Suffrage speakers should be heard at every

\footnotetext{
${ }^{31}$ Effland, “The Woman Suffrage Movemnet in West Virginia,” 38.

${ }^{32}$ Effland, "The Woman Suffrage Movemnet in West Virginia," 40.

${ }^{33}$ Effland, "The Woman Suffrage Movement in West Virginia," 50.

${ }^{34}$ Effland, "The Woman Suffrage Movement in West Virginia," 48.
} 
point in the county where a crowd can be assembled- school house, store, porch or church. " She also asked that every candidate "be officially asked to make favorable mention in all his political speeches.” Moreover, upon Yost's request, two women were to be present at a voting precinct on Election Day. ${ }^{35}$ As the referendum day got closer, Yost urged the campaigners to display a picture poster in every voting precinct ten days before the election. A special leaflet was also to be mailed to voters five or six days before Election Day. ${ }^{36}$

Class disparities between American citizens also infiltrated the woman's suffrage movement. In the nineteenth century, ASWA’s president Lucy Stone, for example, did not believe in associating the suffrage movement with the labor movement. Not only was Stone not supportive of labor reform, she was also critical of labor's methods. In 1892, for instance, she asked "why the Homestead strikers did not save their earnings to start their own business if they were dissatisfied with their jobs.” ${ }^{37}$

Yost did not share Stone's hostility to the working class. She understood the importance of recruiting working class women to the suffrage cause. In West Virginia, it was evident that labor support would make a difference in the outcome of the election. ${ }^{38}$ In fact, the only two counties in West Virginia that gave a majority of its vote for the suffrage referendum were industrial counties. As one of her strategies in the referendum campaign of 1916, Lenna Yost sent the WVESA field secretary to address the State Labor Federation in West Virginia, hoping to educate them on the suffrage question. ${ }^{39}$

\footnotetext{
${ }^{35}$ Lenna Lowe Yost, “West Virginia Equal Suffrage Association,” 25 September, 1916, Yost papers, ADD Box 1.

${ }^{36}$ Lenna Lowe Yost, “West Virginia Equal Suffrage Association,” 14 October, 1916, Yost papers, ADD Box 1.

${ }^{37}$ Kraditor, The Ideas of the Woman Suffrage Movement, 158.

${ }^{38}$ Effland, "The Woman Suffrage Movement in West Virginia," 52.

${ }^{39}$ Effland, "The Woman Suffrage Movement in West Virginia," 53.
} 
As the referendum day got closer, suffragists in West Virginia were confident that the amendment would pass. According to Ida Husted Harper, "the majority of the newspapers were editorially in favor of the amendment." ${ }^{40}$ Moreover, the day before the November 7 election, Yost gave a statement to the Clarksburg Daily Telegram, thanking all the supporters of the suffrage campaign. She also stated that she was confident West Virginia would be the "first eastern and southern state to grant suffrage to its women." 41 An article in The Pendleton Times also reported, "The third week before election ends with the tide setting strong in favor of the suffrage cause in West Virginia.” The article also noted, "With almost no organization to start with, the West Virginia Equal Suffrage Association has built up an effective volunteer work force that is the envy and despair of the older parties." The article assured, "This suffrage campaign will go down in the political history of West Virginia as the most wonderful in the annals of the State." ${ }^{22}$

However, some national NAWSA workers who had gone to West Virginia reported a different scenario. NAWSA activist Eleanore Roul, for example, noted the indifference of West Virginia women towards the suffrage amendment. In June 1916, Roul stated, "I really think suffrage is very difficult up in this part," referring to her observations in Wheeling, West Virginia. ${ }^{43}$ Although she was still hopeful for a win, Roul believed West Virginia was not ready to carry on such an intense state campaign and that the state was also unable to raise sufficient funds for the cause. The local West Virginia association received financial help from the national organization. While West

\footnotetext{
${ }^{40}$ Ida Husted Harper, History of Woman Suffrage, Volume VI (New York: J.J Little \&Ives Company, 1922), 690.

41 "Mrs. Yost Now Sure Of Suffrage Victory,” Clarksburg Daily Telegram, 6 November 1916.

42 "Suffrage Is Sure To Win,” The Pendleton Times, 27 October 1916.

${ }^{43}$ Effland, "The Woman Suffrage Movement in West Virginia," 56.
} 
Virginia was only able to raise $\$ 9,000$, NAWSA reportedly contributed with over $\$ 17,000 .^{44}$

Some local newspapers also reported a lack of interest from both political parties and at times mocked the suffrage referendum in West Virginia as a lost cause in the election of 1916. An article at the Glenville Pathfinder reported, "West Virginians will have the issue of votes for women injected into the campaign as a sort of paprika of feminine touch to the prosaic discussion of the tariff and other dull things.” The article continued, "By a great majority, the clear- eyed women of our acquaintance see and know that the franchise is a burden and not a privilege, and they are not lifting a hand in sight to affect the election,” referring to representatives from both the Republican and Democratic parties. $^{45}$

Anti-suffrage sentiment was alive and well in the state prior to the election, and many newspapers published messages against the amendment. The Clarksburg Daily Telegram published an article on November 2, 1916, explaining why it would not be in women's best interest to obtain the vote. "We oppose the suffrage for women because we feel we have more influence without it;” according to the Telegram, which also felt that women "can exert an influence in the community proportionate to her character and ability." ${ }^{46}$ On November 5, 1916, the Huntington Herald Dispatch noted that "One of the most interesting features of the campaign in West Virginia has been the fight for and against the ratification of the proposed equal suffrage amendment to the constitution of

\footnotetext{
${ }^{44}$ Effland, "The Woman Suffrage Movement in West Virginia," 60.

45 "Ma and the Ballot." Glenville Pathfinder, 31 August 1916.

46 “Liquor Vote On Suffrage,” The Clarksburg Daily Telegram, 2 November 1916.
} 
the state of West Virginia." 47 In the same issue, a paid political advertisement urged voters to reject the amendment for the sake of their families: "I believe that neither the state, the family nor woman herself would be benefited, but on the contrary, would be injured if she were invested with the suffrage.” According to many anti-suffragists, it was against the teachings from the Bible to grant women suffrage. Judge C. B. Bill made the following statement: "God forbid that the destruction of our homes be made possible by an innovation proposed to be brought by a small minority of women agitators.”48

The statements above reflected the fear that, if women were involved in the voting process, they would eventually be drawn into politics as well. Many women and men of the Progressive Era, including many suffragists, scorned politics as corrupt. Although they saw their role as a reforming one, that of cleaning up society, some were careful when defining the position women were to assume in politics once they obtained the vote. This fear fueled and strengthened the anti- suffrage sentiment in the nation. When referring to the possibility of office holding for women, the Clarksburg Daily published, “office holding is, on the face of it, incompatible with women's proper discharge of her duties as wife and mother.”49 Jeff Newberry wrote on November 5, 1916 that "Women cannot have the franchise without going into politics, and the political woman would be a menace to society, to the home and to the state." ${ }^{50}$ The Alabama Christian Advocate urged the WCTU to "leave politics and woman suffrage to be taken

\footnotetext{
47 "Suffragists busy and Antis Quiet Saturday Evening," The Huntington Herald Dispatch, 5 November 1916.

48 “Against Woman Suffrage,” The Huntington Herald Dispatch, 5 November 1916.

49 "Why the Majority of Women Do not Want the Ballot," The Clarksburg Daily Telegram, 2 November 1916.

50 “Against Woman Suffrage,” The Huntington Herald Dispatch, 5 November 1916
} 
care of by the politicians." 51 Even after women were granted the vote, the most ardent suffragists understood the obstacles they faced if they wanted to participate in party politics. According to suffragist Carrie Chapman Catt, there was a distinction between “'voting' into which women had at last been admitted, and 'politics' from which they remained largely excluded.”52

Lenna Yost, however, did not share those views. Instead, she was one of the suffrage supporters who believed that women should be engaged in party politics. Yost shared the perspective of Harriot Stanton Blatch, daughter of famous suffragist Elizabeth Cady Stanton. Blatch urged women not only to fight for the vote but also to be more politically educated and more involved in the political arena. Despite concerns about the corrupting influence of politics, Blatch believed that women should also be concerned with other political matters, such as lobbying senators for important causes. ${ }^{53}$ Yost's political involvement in the Republican Party and her unusual accomplishments for the time firmly support this idea. Not only did she break new ground with her own political career, she also fought for women everywhere to have a voice in their government and to actively participate in political matters.

West Virginia voters went to the polls on November 7, 1916, to decide the presidential election as well as other proposed amendments, including the ratification of the women suffrage amendment in their state. Women's organizations involved in the campaign, including the WVESA, worked hard at the polls in order to convert voters to their cause. According to The West Virginian, “Eighty-eight women working in four

\footnotetext{
51 Joe L. Coker, Liquor in the Land of the Lost Cause, Southern White Evangelicals and The Prohibition Movement, (Kentucky: The University Press of Kentucky, 2007), 216.

52 Ellen Carol Dubois, Harriot Stanton Blatch And The Winning Of Women Suffrage (New Haven and London: Yale University Press, 1997), 124

${ }^{53}$ Dubois, Harriot Stanton Blatch and the Winning of Women Suffrage, 125.
} 
different shifts are constantly at the polls, the women have arisen early and taken up their posts when the polls where opened.” Moreover, "The women give to each voter a neat card on which is printed the information that each political party has endorsed suffrage and asking that the men give their sanction to the movement by casting their vote for the suffrage amendment." 54

Unfortunately, the state referendum campaign in West Virginia was not successful. Despite the effort West Virginia suffragists had put into the campaign, the margin of defeat, 63,540 to 161,607 , was "the largest ever given against woman suffrage.” Out of West Virginia’s fifty- five counties, only two, Brooke and Hancock, gave a majority of the votes for the amendment. ${ }^{55}$

In attempting to explain the reasons for the defeat of the suffrage cause in West Virginia, some historians focus on the fact that the suffrage movement was tightly connected to the prohibition movement. Women throughout the country were leaders and principal advocates of both causes. As discussed earlier, the WCTU provided women, such as Lenna Yost, with the training ground they needed to work for other reforms, including suffrage. Although not all women who were members of the WCTU supported woman suffrage, many grew increasingly frustrated with their lack of political power when fighting for other reforms that were close to their heart, such as child labor, better wages for women, and prohibition. Skilled organizers and speakers from WCTU, such as Yost, were a great asset for the suffrage cause. She had already acquired extraordinary leadership skills as the president of the West Virginia chapter of the WCTU and, therefore, became the obvious choice to lead the suffrage movement in her state. Her

\footnotetext{
54 "Women Work At Polls Today For Suffrage Cause, Were on the Job Early and Remained All," The West Virginian, 6 November 1916.

${ }^{55}$ Harper, The History of Woman Suffrage, 692
} 
success as president of the West Virginia WCTU in contributing to the passage and implementation of one of the strictest state prohibition laws in the country proved her to be a worthy leader. Like Frances Willard had done before, Yost was able to use her influence as president of her state's WCTU to bring the woman suffrage issue before prominent citizens and politicians of her state.

However, the connection between prohibition and suffrage also generated an array of anti-suffrage sentiment among some Americans. Because of Yost's involvement with the prohibition movement and the successful enforcement of the Yost Law in West Virginia, her leadership caused complications for the woman suffrage movement. On one hand, some temperance supporters disagreed with the principles of women suffrage and, therefore, despised any WCTU support for the cause. On the other hand, "wets” and saloonkeepers were fearful that, once women got the vote, they would use their political power to enact and strengthen prohibition laws in the country. For example, in explaining the differences between how males and females would exercise their right to vote, Octavious B. Frothingham implied that the women "would close all the bars and liquor saloons, and make it a crime to sell intoxicating drink."

Anne Effland asserts, "it is hard to conclude that the liquor interest had any significant effect on the outcome of the election." ${ }^{57}$ An article in The Glenville Pathfinder also reported, “The largest vote ever given for prohibition was given by male suffrage states, and the largest vote given against prohibition was by equal suffrage states.”58 Although several factors must have influenced the defeat, it is impossible to ignore the connection between the prohibition movement and the woman suffrage movement in

\footnotetext{
${ }^{56}$ Kraditor, The Ideas of the Woman Suffrage Movement, 19.

${ }^{57}$ Effland, "The Woman Suffrage Movement in West Virginia," 80.

58 "Equal Suffrage,” The Glenville Pathfinder, 26 October 1916.
} 
West Virginia, particularly since the “'wet' vote of Wheeling, Huntington and Charleston proved a decisive factor in defeating the amendment." ${ }^{59}$ As historian Marjorie Spruill Wheeler points out in One Woman, One Vote, the WCTU's support "gained for the suffrage movement a powerful opponent when the liquor industry concluded that women suffrage was a threat to be stopped at all costs. ${ }^{\prime 60}$ Later, in 1919, during the battle for the ratification of the federal woman suffrage amendment, M.L Rankin explained his concerns to Yost as well. "I am for Suffrage because I am a Republican because the AntiSuffrage forces of this County have always been behind rum, bossism and rebellion.” Rankin also added, "I know of no liquor maker who stands for Suffrage." 61

It was also clear that some prominent leaders of the suffrage movement worried that Yost's association with prohibition hurt the suffrage cause. The tension between the suffrage campaign and the liquor interests was evident in West Virginia. On November 5, 1916, The Clarksburg Sunday Daily Telegram published an article on women suffrage directed towards those opposing the amendment, urging them to reconsider their position. According to the editorial, "in every instant where woman suffrage is submitted in any state it is fought by every interest connected with the liquor traffic." ${ }^{\prime 62}$ Another bitter article published in The Telegram on November 1, only a few days before the election, was aimed towards the 'wets' of the state. "I always did think that it was a funny law that would let an old whiskey-soaked lobster of a ward heeler vote,” and yet would keep righteous, well respected women from voting. The article goes on to say that "nine-tenths of the opposition to woman suffrage crawled and wriggled out of the breweries and the

\footnotetext{
${ }^{59}$ Harper, The History of Woman Suffrage, 692.

${ }^{60}$ Wheeler, One Women, One Vote, 12.

${ }^{61}$ Rankin to Yost, 30 July, 1919, Yost Papers, Box 1.

62 “Woman Suffrage,” The Clarksburg Sunday Telegram, 5 November 1916
} 
distilleries. They know that when the women go to the polls and drop a ballot it will be the doom of the grog shop." ${ }^{, 3}$ Suffragists published on The Clarksburg Telegram two days before the election, "Would it not be to your better interests and show better taste to work for influence for yourselves to help humanity, than to work with the liquor and vice interests against yourselves and your sisters?" ${ }^{4}$

The hostility toward the "wets" helped reaffirm for supporters of the liquor traffic attitudes about the dangerous outcomes associated with woman suffrage. Therefore, many suffrage advocates understood the downside of the tension between temperance and suffrage. On November 2, an article entitled "Liquor Vote On Suffrage" in The Clarksburg Daily Telegram urged suffragists "to make their peace with the liquor element," stating that "the only way to get the ballot is to prove that equal suffrage is not the advance agent of prohibition." 65

Effland also points to the fact that Ohio County, West Virginia, voted against prohibition in 1914, but did not vote overwhelmingly against the suffrage referendum, to suggest that prohibition was not the principal issue ${ }^{66}$ However in 1916, compared to other states, West Virginia experienced the worst defeat related to the women suffrage cause. At that time, Yost was the leader of both campaigns, and her husband's strict prohibition amendment had been in effect for two years. Moreover, in Woman Suffrage and Politics, then NAWSA's president, Carrie Chapman Catt, also made a reference to the referendum defeat, blaming it on the fact that "the same woman was the president of the state's Woman's Christian Temperance Union and the Suffrage Association,”

\footnotetext{
63 “ 'Billy Sunday’ on Votes for Women,” The Clarksburg Daily Telegram, 1 November 1916

64 “Woman Suffrage,” The Clarksburg Daily Telegram, 5 November 1916.

65 “Liquor Vote On Suffrage,” The Clarksburg Daily Telegram, 2 November 1916

${ }^{66}$ Effland, “The Woman Suffrage Movement in West Virginia,” 81.
} 
referring to Yost. According to Catt, "the wets were infuriated by the Prohibition victory” of 1914 in West Virginia, causing them to conspire against the suffrage amendment. $^{67}$

Concrete evidence for the connection between the defeat of women suffrage in West Virginia and the liquor interests in the state is tough to find. As the National Woman Suffrage Publishing Company described it, “To be asked for evidence of an organized opposition to woman suffrage on the part of the liquor interests, is to the suffragist, like being asked to blow up a card house with dynamite.” Nevertheless, the company managed to gather convincing proof of such connection based on paid advertising published in the Progress and the National Forum, leading official organs of some state retail liquor dealers. Headlines in these newspapers alerted, "Give Ballot to Women and the Industry Goes to Smash.” Published anti-suffrage sentiments contained statements such, "If women get the ballot it means prohibition;" "Women suffrage means prohibition;" "Can you imagine what it means to the brewery industry, to the saloon trade, to the farmer, to the manufacturer, to the dealer and the workingman?” In Michigan, the Progress pledged that, "It is the duty of all men of this State, who love their home, their family, their liberty, their rights and their citizenship to go to the polls on November 5 and vote against this constitutional amendment.” Another article added, “A campaign against woman suffrage and other dangers of the brewing and affiliated industries that threaten the trade is to be waged by PROGRESS from now on until the fall election." 68

\footnotetext{
${ }^{67}$ Carrie Chapman Catt and Nettie Rogers Shuler, Woman Suffrage And Politics, The Inner Story Of The Suffrage Movement ( Seattle and London: University Of Washington Press, 1923), 301.

68 "Women Suffrage and the Liquor interests," February 1916, Yost Papers, Box 2.
} 
Other factors also contributed to the defeat. The anti-suffrage movement in the United States formed a well-organized opposition. Both men and women opposing the amendment formulated reasonable and strong arguments against the suffrage cause. Antisuffrage articles published statistics such as, "DO YOU KNOW. That women receive no better law in Equal Suffrage states than in male suffrage states, and when equal pay for equal work is given, women are discharged and men employed, because men work more steadily and for longer years than women.” Anti-suffragists also asked, "DO YOU KNOW. That in no men suffrage state is the wife called upon to support the husband as in the woman's suffrage states where non- support of a husband is ground for divorce.”69 The Glenville Pathfinder reported, “In equal suffrage states, the husband's obligation to his wife is taken away. He is not liable for her support and her debts, because they are on an equal footing."70 An anti-suffrage article in The Clarksburg Telegram explained, "political equality will deprive woman of special privileges hitherto accorded to her by law." ${ }^{71}$ Tactics such as these contributed to women being hesitant about obtaining political power.

Out-of-state critics of the vote for women also carried the anti-suffrage campaign in West Virginia. For example, New Jersey anti-suffrage organizer Mrs. Oliver D. Oliphant was an energetic and excellent public speaker in West Virginia. She allegedly traveled to several parts in the state and was a strong asset in preventing the suffrage referendum from achieving victory in West Virginia. ${ }^{72}$ In an article she wrote for The Clarksburg Telegram, Oliphant emphasized the fact that in states where women were

\footnotetext{
69 “Woman Suffrage,” Glenville Pathfinder, 21 September 1916.

70 “Equal Suffrage,” Glenville Pathfinder, 26 October 1916.

71 "Why the Majority of Women do not Want the Ballot," The Clarksburg Daily Telegram, 2 November 1916.

${ }^{72}$ Effland, “The Woman Suffrage Movement in West Virginia,” 73.
} 
allowed to vote, they were also required to serve on juries." She was hopeful that this fact would "win votes against women suffrage in sections of the state," referring to West Virginia.,73

Another common argument against the vote was based on surveys, which showed that the majority of women in the nation did not want the vote. According to Mrs. Arthur M. Dodge, president of the national anti-suffrage association, $90 \%$ of women did not want voting rights. ${ }^{74}$ Many anti-suffragists believed that the men were properly representing them in the public sphere, and, therefore, the vote was not necessary. Some also emphasized the biological differences between women and men as a reason why women should not be involved in politics. Harry Temple of Pendleton County, West Virginia, stated, "Woman is, by her very nature, constitutionally and organically disqualified for the service of the state.” Moreover, woman "has not the cerebral organization adapted to the close, protracted, and harassing study of state affairs, nor a nervous organization equal to the sustained exertion and endurance demanded by judicial and legislative duties..."75 Another article in the Glenville Pathfinder concluded, "The mother's place is in her home where she is queen, and where her deeds and virtues wield and influence for good that reaches the world."76

Understanding the reasons for the 1916 suffrage campaign loss was crucial for the ratification of the Nineteenth Amendment in West Virginia in 1920. When the moment arrived for members of the West Virginia legislature to vote for the ratification of a federal suffrage amendment in 1920, lawmakers referred to the 1916 defeat. Senator

\footnotetext{
73 "Mrs. Oliphant is Quite Grateful to Suffragists for their Convincing Proof that Women Do Serve on Juries,” The Clarksburg Daily Telegram, 5 November 1916.

${ }^{74}$ Effland, "The Woman Suffrage Movement in West Virginia," 69.

${ }^{75}$ Effland, "The Woman Suffrage Movement in West Virginia," 67.

76 "Equal Suffrage," Glenville Pathfinder, 26 October 1916.
} 
Wallace B. Gribble explained to Yost in 1920, "You are aware that when I was elected to the Senate, the voters of this State gave an expression of their wishes on this question and I feel that I am bound by that result." ${ }^{, 7}$ That same year, The Clarksburg Daily Telegram reported, "In taking his stand against ratification of the amendment, Senator Gribble points to the overwhelmingly majority against suffrage given at the polls in this state in 1916." ${ }^{78}$ West Virginia Delegate Albert J. Kern, although a supporter of suffrage, also expressed his concerns to Yost in 1919 with, "Some," referring to the lawmakers in West Virginia, "might be persuaded that the result in the State on that distinct issue," the referendum, "is still binding.,"79 Senator Milton Burr, also in 1919, wrote, "The voters in this senatorial district in 1916, by a large majority, opposed the suffrage amendment.” Burr added, "I do not know there has been any decided change in the attitude of the people towards this question, and for that reason, if a special session of the Legislature is called to consider the Federal amendment, I expect to vote against it." ${ }^{80}$ West Virginia Senator A. E. Scherr wrote Yost in 1920, "Due to the actions of the voters in the State of West Virginia, just a few years ago on this subject, I am inclined to follow their direction, as I feel that it is my duty to do so." ${ }^{81}$

Clearly, Lenna Yost must have been frustrated with the defeat in 1916. She held the suffrage cause close to her heart. However, she expressed full knowledge of the reasons for the crushing vote, blaming it on "the conservatism deeply entrenched in West

\footnotetext{
${ }^{77}$ Gribble to Yost, 2 February, 1920, Yost Papers, Box 2.

78 "Suffrage Resolution is Introduced in Senate by Senator Harvey Harmer, Gribble Leading Fight Against it,” The Clarksburg Daily Telegram, 27 February 1920.

${ }^{79}$ Kern to Yost, 1 September, 1919, Yost Papers, Box 1.

80 Burr to Mrs. B.B Wheatley, 6 October, 1919, Yost Papers, Box 1.

${ }^{81}$ Scherr to Yost, 17 February, 1920, Yost Papers, Box 2.
} 
Virginia’s poor, indifferently illiterate and hardscrabble rural counties.”2 Both Brooke and Hancock counties, where the majority of votes had gone in favor of the amendment, were located in the northern part of the state and were considered industrial counties. Yost added, "The fact that our state has such a large rural population and poor railroad facilities and bad country roads entered into the defeat.” Disappointed by the defeat, Yost also blamed it on "the indifference and the opposition of women" in West Virginia. ${ }^{83}$ In fact, many suffragists of the time believed the indifference of women to be a powerful obstacle to the suffrage cause. ${ }^{84}$ According to many, women were not ready for the vote in 1916. Some of the opponents in 1916 would later support the federal suffrage amendment in 1920, stating that women's contribution in World War I matured them in the public sphere and prepared them for the vote. The chairman of the West Virginia Republican Committee, W.E. Baker, who was against suffrage in 1916, explained to Yost in 1919 that, "the late war has changed many things and I am now in hopes that our Legislature may convene and the amendment passed in time to let our ladies in West Virginia participate in the election of 1920.”85 Major John C Bond, Republican candidate for State Auditor, also acknowledged "the sacrifices made by women of America during world war which entitle them to the lasting consideration of mankind, their right to the ballot is unquestioned." 86

Yost did not make a reference to the connection between the defeat and the prohibition cause in West Virginia she so ardently supported, at least not publicly. Later

\footnotetext{
${ }^{82}$ Sarah Baldwin, "Lenna Lowe Yost Archives Chronicle the Woman Suffrage Movement in State and Nation,” West Virginia and Regional Collection Newsletter, Volume 19, No. 1, 2003, West Virginia and Regional Collection, West Virginia University, Morgantown, WV.

${ }^{83}$ Yost to Harper, 1921 (undated typescript), Yost Papers, Box 2.

${ }^{84}$ Wheeler, Rediscovering the Woman Suffrage Movement, 161.

${ }^{85}$ Baker to Yost, 15 September, 1919, Yost Papers, Box 1.

86 "Major John C. Bond, Republican candidate for State Auditor, gave empathetic endorsement to the cause of equal suffrage in a statement to Mrs. Yost,” (undated typescript), Yost Papers, Box 2.
} 
however, the subject proved to be a sensitive one for her. During the campaign for the ratification of the federal women suffrage amendment in 1919, aware of the strictness of the prohibition laws in West Virginia, Carrie Chapman Catt expressed her concerns to Yost in regards to the temperance cause and its effects on the suffrage movement. “Although West Virginia is a 'dry' state, there is a tremendous amount of very lively 'wet' sentiment there and if the idea prevails that this is a strictly 'dry' movement, you may happen to lose a single vote in the legislature which would be crucial," Catt wrote Yost. Catt then urged Yost to make sure to include members in her campaign as president of the ratification committee that did not belong to the 'dry' side of the West Virginia. ${ }^{87}$ Yost was clear and detailed in her response to Catt, asserting that "wets” were very much part for her campaign. She asserted to Catt in 1919, "Not a member of our State Central Ratification Committee was ever affiliated with the prohibition work. ${ }^{88}$

The devastating loss suffragists suffered in West Virginia in 1916 might also have helped influence NAWSA to invest completely in a federal suffrage amendment campaign, following in the footsteps of its rival, the NWP. New York had also suffered a disappointing loss only a year earlier with its state suffrage amendment proposal. ${ }^{89}$ "In 1916 the NAWSA adopted a new policy toward the federal amendment, ending its long period of almost exclusive concentration on the states,” according to historian Aileen Kraditor. ${ }^{90}$

Exhausted by the 1916 loss in West Virginia, Yost decided to bring her focus back to the WCTU. She stepped down from the presidency of the WVESA and moved to

\footnotetext{
${ }^{87}$ Catt to Yost, 25 September, 1919, Yost Papers, Box 1

${ }^{88}$ Yost to Catt, 2 October, 1919,Yost Papers, Box 1.

${ }^{89}$ Dubois, Harriot Stanton Blatch and the Winning of Women Suffrage, 178

${ }^{90}$ Kraditor, The Ideas of the Woman Suffrage Movement, 9.
} 
Washington D.C. to become the national correspondent for the WCTU, writing for Our Washington Letter in the Union Signal. ${ }^{91}$ She continued to keep close contact with the suffrage movement, however. Not only did Yost not give up on the suffrage cause, her 1916 state campaign laid the groundwork for the 1919 federal suffrage amendment campaign in West Virginia.

After generations of trying to win the vote in state-by-state battles, suffragists decided to approach their representatives from a different route. A federal amendment granting women the vote became the goal for the main suffrage organizations. Woman reformers from all over the country, including Harriot Stanton Blatch, Carrie Chapman Catt, Alice Paul, and Lenna Lowe Yost, concentrated their energy on this approach. They pressured President Woodrow Wilson and the United States Congress to introduce a federal amendment granting women the right to vote. When the moment for a decision arrived once more in her state, Lenna Lowe Yost was up for the challenge.

\footnotetext{
91 “Biographical Notes,” (undated typescript), Yost Papers, Box 1
} 


\section{Chapter 4: Lenna Lowe Yost and the Ratification of the Federal Woman Suffrage Amendment in West Virginia}

"Woman Suffrage will soon be an accomplished fact. Emancipation of woman has proceeded slowly, but is now in our immediate view and we look forward with happy anticipation to her full and equal participation in political and business, as well as social affairs with man."1

Wells Goodykoontz

Women gained the right to vote across the country in 1920, but the journey proved to be a tough one. This achievement would not have been possible without the cooperation of many different groups and most importantly, the courage of individual leaders whose dedication to the cause inspired those around them. In 1919, the National American Women Suffrage Association (NAWSA) appointed Lenna Lowe Yost as chairman of the Ratification Committee of the West Virginia Equal Suffrage Association (WVESA), an affiliate of NAWSA, and started a decisive battle for the anticipated federal woman suffrage amendment. Throughout the years of 1919 and 1920, at the height of the woman suffrage movement, Yost's work and dedication to the suffrage cause earned her a spot among the most noted women reformers of her era.

In 1916, under Lenna Yost's leadership, West Virginia suffragists had endured a terrible defeat in their state referendum campaign. From that point on, NAWSA concentrated its efforts solely toward campaigning for a federal suffrage amendment. On June 4, 1919, Congress passed a proposed amendment, often called the Susan B. Anthony amendment, granting women the right to vote. The House of Representatives passed the amendment by a majority vote of 304 to 89 . The Senate followed by passing the amendment as well. To complete the ratification of the

\footnotetext{
${ }^{1}$ Wells to Yost, 14 February, 1920, Lenna Lowe Yost Papers, ADD Box 2, West Virginia and Regional History Collection, West Virginia University, Morgantown, WV, (hereafter, Yost Papers).
} 
amendment, three-fourths of the nation's states still needed to ratify it. Aware of these requirements, Yost, who was then residing in Washington D.C, returned to West Virginia and initiated a series of campaigns to get West Virginia legislators to ratify the amendment.

Only a month after Congress had ratified the amendment, Yost was eager to organize the women of her state. One of her first measures was to eliminate the myth that women did not desire to vote. She urged West Virginia suffragists to sign a petition to the state's legislature requesting ratification of the nineteenth amendment. ${ }^{2}$ As the suffragists neared the magic number, each remaining state became a critical battleground. The amendment, which granted all American women the right to vote, would be formalized when thirty-six state legislatures ratified the amendment. West Virginia eventually became the thirty-fourth state to do so, making the debate within that state especially crucial for the victory. With Yost as their leader, West Virginians engaged in a long lasting battle that would prove to be worth remembering for generations to come.

The states yet to ratify the amendment did not have their legislative sessions scheduled until after the Presidential elections of 1920. West Virginia, for example, did not have a regular session scheduled until the winter of $1921 .^{3}$ Therefore, the governors of those states had to agree to call special sessions of the legislature so that members of those states' legislatures could vote for woman suffrage not only for the presidential elections of 1920, but also in time for the presidential primaries in that same year.

\footnotetext{
${ }^{2}$ Lenna Lowe Yost, “West Virginia Equal Suffrage Association,” 5 July, 1919, Yost Papers, Box 1.

${ }^{3}$ Yost, “West Virginia Equal Suffrage Association,” 5 July, 1919, Yost papers, Box 1.
} 
West Virginia Governor, John Jacob Cornwell, had shown an inclination to support the ratification of the federal amendment. However, before Governor Cornwell called a special session, he urged Lenna Yost to use her influence and lobbying strategies to guarantee that the majority of the state legislators agreed on the need to call the session, and, if called, would vote in favor of the amendment. When Lenna Yost took over the Ratification Committee in West Virginia, it was clear that suffragists depended upon her tactics and experience. Cornwell wrote to Yost with some urgency that, "I think it might be very well for you to take up with the members of the Legislature the question of signing a petition for a special session." 4 Lenna Yost returned to a West Virginia suffrage movement divided by loyalties to different approaches and ideologies. According to historian Nancy F. Cott, "The woman movement at the turn of the century was manifesting groundswells of change resulting from the increasing differentiation and heterogeneity among women in America." 5 Wars, imperialistic ideas, segregation, immigration, industrialization, and urbanization intensified the changes in American society in the 1910s, presenting a challenge for women reformers all over the nation. As organizations from all backgrounds increased their participation in the public arena in order to protect their interests, loyalties to associations, race, gender, political parties, and class diversified the woman suffrage movement in West Virginia. These different identities of women needed to find a common ground to achieve their social and political goals. As a result, they were to some degree

\footnotetext{
${ }^{4}$ Cornwell to Yost, 12 January, 1920,Yost Papers, Box 1.

${ }^{5}$ Nancy F. Cott, The Grounding of Modern Feminism (New Haven and London: Yale University Press, 1987), 21.
} 
forced to collaborate with one another. As Cott pointed out, the 1910s "was the only decade in which women suffrage commanded a mass movement, in which working class women, black women, women on the radical left, the young, and the upper class joined in force." 6

Both NAWSA and its rival, the National Woman's Party (NWP) had established headquarters in West Virginia. Although the two organizations were campaigning for a federal amendment at that point, they pursued different strategies. While Alice Paul, leader of the NWP, adhered to her radical tactics of "punishing the party in power" for not supporting the suffrage amendment, Carrie Chapman Catt continued advocating for a less confrontational route. Paul and her close friend, Lucy Burns, had lived in England, and, therefore, were influenced by the British militant suffragists' more radical approaches toward their government. Paul's organization continued picketing outside the White House, generating anger from citizens and members of NAWSA. According to Woman Suffrage and Politics, NAWSA did not endorse the "so-called militant methods."

The hostility between these associations was evident in West Virginia. Upon Yost's request for Izetta Brown to become a member of the WVESA, Brown answered, "I just imagine that my belonging to the Woman's Party would make me ineligible for the work you suggest." 8 In a letter Yost wrote to Mrs. Edwin C. Ewing, a prominent member of the state's women's club, one can observe the general resentment towards the militant methods. Yost wrote, "I can very well appreciate

\footnotetext{
${ }^{6}$ Cott, The Grounding of Modern Feminism, 30.

${ }^{7}$ Carrie Chapman Catt and Nettie Rogers Shuler, Woman Suffrage And Politics, The Inner Story of The Suffrage Movement (Seattle and London: University Of Washington Press, 1923), 245.

${ }^{8}$ Brown to Yost, 17 December, 1919, Yost Papers, Box 1.
} 
your lack of sympathy with the 'coercive tactics' used by a very few women to secure suffrage, but I do not think the militant methods used by such a small number, comparatively speaking, should in any way interfere with the complete cooperation of women to establish a great principle." ${ }^{\prime 9}$ Yost however, did request NWP members to serve on the Advisory Committee of the WVESA as well, displaying eagerness for cooperation between the two organizations in order to more effectively ensure the ratification of the amendment. Florence Hoge of the NWP wrote Yost, "Yes, indeed I will serve on the committee if I may do so as Chairman of the Woman's Party in W.Va."10

As class disparities also intensified in the twentieth century, working-class women, rural women, and socialites often interacted at the various women's organizations to which they belonged. Leaders of the suffrage movement, although ultimately aiming at obtaining the vote, believed in it for different reasons. Some middle-class and upper-class white women argued for the vote alleging they would decrease the influence of illiterate voters, referring to poor immigrant males. Articles in newspapers published comments such as, "The dangerous possibilities of the slacker, the ignorant, and the alien vote are said to be arousing Southern men and women especially to the immediate national urgency of the women suffrage question." ${ }^{11}$ Others, such as Harriot Stanton Blatch, believed "it was a mistake to identify literacy with enlightment."12 The labor movement in the United States

\footnotetext{
${ }^{9}$ Yost to Mrs. Ewing, 7 November, 1919, Yost Papers, Box 1.

${ }^{10}$ Hoge to Yost, 1 November, 1919, Yost Papers, Box 1.

11 “On the Suffrage Line,” (undated typescript), Yost Papers, Box 2.

${ }^{12}$ Aileen S. Kraditor, The Ideas of the Woman Suffrage Movement, 1890- 19020 (New York and London: W.W. Norton \& Company, 1981), 135.
} 
influenced wage-earning women to lend their support to the suffrage cause. The need for the ballot and political representation were connected to the betterment of conditions in factories and the economic justice they longed for.

As West Virginia became a battleground for suffragists, Lenna Yost was confronted by the diversities within the movement. While still maintaining her convictions, she was able to target different groups of women, understanding the essential contributions that each distinct social class and movement of the era could bring to the suffrage cause. For example, Yost requested, "In rural sections where a systematic personal canvass of the homes of the women cannot be made, you are urged to take advantage of all indoor and outdoor public gatherings to secure the signature of women." 13 Moreover, her ability to navigate through different ideologies and parties, and thereby exert the necessary amount of pressure in her state, contributed to the success of the movement in West Virginia. As Florence Hoge of the NWP acknowledged, "what you are doing, the petition work and getting resolutions passed by different organizations seems to me very good."14 Martha Brock later said of Yost, "Her personal appeal, which never fails to interest, literally disarms prejudice and rarely fails to enlist effective cooperation." 15 Although an ardent Republican, her relationship with Democrats, such as Clement L. Shaver, chairman of the Democratic State Committee, and especially Democratic Governor John Cornwell was one of respect and mutual appreciation, which was essential to achieving the final victory of the suffrage cause in her state. When attorney Clyde B.

\footnotetext{
${ }^{13}$ Lenna Lowe Yost, “West Virginia Equal Suffrage Association,” 5 July, 1919, Yost Papers, Box 1.

${ }^{14}$ Hoge to Yost, 1 November, 1919, Yost Papers, Box 1.

${ }^{15}$ Martha Brock, “(Mrs. Ellis A.) Lenna Lowe Yost,” (undated typescript), Yost Papers, Box 3.
} 
Johnson advised Yost to get both Democrats and Republicans to be among the first to sign a petition for a special session of the legislature, he found Yost already prepared to accomplish the task. Johnson praised Yost: "it is a waste of time for me to attempt to tell you how to put a thing of this kind over. Might I say that it would be attempting to paint the lilly and perfume the rose." 16

When the fight for a federal amendment granting women the right to vote became the focus in West Virginia, Julia M. Ruhl, a Connecticut native and former teacher, was serving as the president of the WVESA, a position she had taken over from Lenna Yost in 1917. Ruhl recruited Yost and Mary Wilson to direct the West Virginia Ratification Committee, which was a moderate organization. The committee also had a State Advisory Committee, made up of influential people whom Yost personally recruited, including lawyers, businessmen, politicians, Secretary of State Houston G. Young, and Ellis A. Yost.

Since the WVESA was affiliated with NAWSA, most of its members were not fond of the NWP. Although West Virginia women were ready to campaign for a federal suffrage amendment, Alice Paul's militant leadership still proved to be too extreme for many of the suffragists in West Virginia. For example, Julia Ruhl wanted to make it clear to the U.S. senator from West Virginia, Howard Sutherland, that the WVESA was not supportive of the NWP philosophy. "The Woman's Party has almost no representatives in our State," Ruhl insisted. She claimed that the West Virginia suffragists did not want to "add to the perplexities and burdens of the hour by acts

\footnotetext{
${ }^{16}$ Johnson to Yost, 22 January, 1920, Yost Papers, Box 2.
} 
which are both illegal and unbecoming."' 17 Later, in a letter Julia Ruhl sent Yost in 1920, she praised Yost's more subtle approach in West Virginia: “A vociferous campaign," such as the ones the NWP advocated, "would have been fatal here."18

The NWP did pressure Governor Cornwell, however, urging him to call the special session. Letters from the NWP addressed to the Governor contained statements such as, "Shall it be that we have sent men to die abroad for democracy, which now includes German women, and continue to refuse it to our own here at home?" The NWP also made clear its unalterable desire to win the vote by a federal amendment; "the right to have a voice in our government is what we American women are asking, and we are not content with having it given piece-meal, state by state," Florence Bayard Hilles, Delaware State chairman, stated. ${ }^{19}$ Cornwell did not seem to maintain a close contact with any member of the NWP, but he did answer their requests promptly.

Lenna Yost managed the different branches of her committee closely and requested reports on progress often. She asked suffragists to "appoint your committees to make your plans and carry out and report your plans within the next two weeks, and your progress every two weeks after that." ${ }^{20}$ Although the special session of the legislature had not been called, Yost worked on getting suffrage campaigners ready in West Virginia. She used a living petition strategy, in which she asked many women to go to Charleston, especially at the first day of the session of

\footnotetext{
${ }^{17}$ Anne W. Effland, “The Woman Suffrage Movement in West Virginia, 1867-1920,” (MA Thesis, West Virginia University, 1983), 99.

${ }^{18}$ Ruhl to Yost, 25 January, 1920,Yost Papers, Box 2.

${ }^{19}$ Hilles to Cornwell, 5 January, 1920, John Jacob Cornwell Papers, West Virginia and Regional History Collection, West Virginia University, Morgantown, WV (Hereafter, Cornwell Papers).

${ }^{20}$ Lenna Lowe Yost, “West Virginia Equal Suffrage Association,” 5 July, 1919, Yost Papers, Box 1.
} 
the legislature to persuade their senators and delegates to vote for suffrage. She also instructed suffragists, both men and women, to send telegrams urging lawmakers to vote for the amendment on the day that a special session was called. ${ }^{21}$

Yost started communication with members of the West Virginia Legislature about the possibility of a special session, asking for their support for ratification when the moment for the decision arrived. She wrote to several state senators stating, "With a rumor of a special session of the West Virginia Legislature, when the ratification of the Federal Suffrage Amendment will be considered, the thoughts of the women of the State turn to those members in the Senate and House who will give their support by their vote for this amendment." She asked, "May we not confidentially expect this favorable consideration on your part?"22 Yost received several replies from lawmakers, assuring her of their collaboration in favor of ratification when the Legislature convenes. Senator Fred L. Fox answered that he was voting for the amendment. ${ }^{23}$ Senator Joseph Sanders, although reluctant to make his decision public, also guaranteed Yost he was in favor of women suffrage. ${ }^{24}$ Likewise, Senator C.C. Coalter assured Yost that, if the special session were called, he would vote for ratification. ${ }^{25}$

When her requests for support went unanswered, Yost urged suffrage advocates in the Senate and the House, such as senator Edgar B. Stewart, to pressure their colleagues. ${ }^{26}$ Stewart kept Yost informed on those who opposed and those who

\footnotetext{
${ }^{21}$ Yost to Mrs. Ebert, 8 September, 1919, Yost Papers, Box 1.

${ }^{22}$ Yost to Senator Polling, 31 July, 1919, Yost Papers, Box 1.

${ }^{23}$ Fox to Yost, 2 August, 1919, Yost Papers, Box 1.

${ }^{24}$ Sanders to Yost, 1 August 1919, Yost Papers, Box 1.

${ }^{25}$ Coalter to Yost, 4 August, 1919, Yost Papers, Box 1.

${ }^{26}$ Yost to Stewart, 11 August, 1919, Yost Papers, Box 1.
} 
could be persuaded based on party expediency arguments, which helped Yost develop her strategies. ${ }^{27}$ Moreover, aware of some lawmakers' hesitance in making their decision of supporting suffrage public, Yost mentioned in her correspondences with them, "no publicity will be given to your reply." 28 Yost also pressured both state committees, Republican and Democratic, to make their decisions for the amendment public, alleging this was the case in other states where the amendment had been ratified. ${ }^{29}$ Obtaining positive responses from the majority of the members of the legislature was crucial for Governor Cornwell to call a special session early in 1920.

Lenna Yost met Governor Cornwell on August 1919, while she was serving as the chair of the Ratification Committee in West Virginia. Shortly after, she started working closely with him, as well as with members of the legislature and other influential citizens to create the pressure needed to pass the amendment in her state. She needed three- fifths of both houses to sign the petition for a special session in West Virginia. Delegate W.R. Godfrey explained to Yost, "The only way I know of to secure an extra session of the Legislature for this purpose is to secure sufficient members of the Senate and House of Delegates who will ask the Governor to call an extra session, and I take it that you are working along these lines." ${ }^{30}$ Aware of this fact, Yost maintained regular correspondence with prominent state leaders

\footnotetext{
${ }^{27}$ Stewart to Yost, 29 September, 1919, Yost Papers, Box 1.

${ }^{28}$ Yost to Hackney, 28 August, 1919, Yost Papers, Box 1.

${ }^{29}$ Yost to Mr. Highland, 19 September, 1919, Yost Papers, Box 1.

${ }^{30}$ Godfrey to Yost, 31 August, 1919, Yost Papers, ADD Box 1.
} 
like U.S. Senator Howard Sutherland, as well as twenty-two out of the thirty state senators in West Virginia. ${ }^{31}$

One of her supporters, attorney Clyde B. Johnson, sent a letter to Yost on January 22, 1920, which contained copies of a "written application by the members of the legislature to the Governor," asking Cornwell to call the session. Johnson also mentioned to Yost that he could not guarantee that the number needed to sign the petition would be achieved. He did, however, believe that, with Yost's "organizing ability and judgment of men and women in this state," she could put together an effective committee to fight for the signatures in each of the West Virginia districts. ${ }^{32}$

Lenna Yost had several replies to her requests for signing the petition for a special session. Some guaranteed her that they were going to support the amendment. For example, Mayor Grant P. Hall wrote Yost in February 1920 that "you will have my hearty co- operation in the securing of the unanimous vote for ratification." ${ }^{33}$ Howard Sutherland, who had voted for the amendment before, also supported it this time, and was happy to "cooperate in any way" with the suffrage cause. ${ }^{34}$ Suffrage advocate and state senator Harvey W. Harmer requested the privilege of being the one to introduce the amendment in the session. He expressed to Yost that he felt strongly about it since he was the first to start the "ball rolling in

\footnotetext{
${ }^{31}$ Sarah Baldwin, "Lenna Lowe Yost Archives Chronicle the Woman Suffrage Movement in State and Nation,” West Virginia and Regional History Collection Newsletter, Volume 19, No. 1, 2003, West Virginia and Regional Collection, West Virginia University, Morgantown, WV.

32 Johnson to Yost, 22 January, 1920, Yost Papers, ADD Box 2.

${ }^{33}$ Hall to Yost, 17 February, 1920, Yost Papers, ADD Box 2.

${ }^{34}$ Sutherland to Yost, 10 February, 1920, Yost Papers, ADD Box 2
} 
the West Virginia legislature, by offering a suffrage amendment in 1895."35 Other members communicated to Yost about their refusal to support the cause. G.W. McCauley, a member of the West Virginia House of Delegates, was "inclined against the proposition," as he made clear to Yost on February 13, 1920. ${ }^{36}$

The situation in West Virginia was peculiar since Governor John J. Cornwell was hesitant to call the special session. Cornwell was waiting for the resolution of a lawsuit concerning a tax on oil and gas companies that the state had approved but that the oil companies were appealing against in Court. If overturned in the Court, Cornwell would have to call a special session to resolve the issue. Cornwell did not believe that it would be wise or popular with the voters to call two special sessions in one year. Therefore, initially, he wanted to wait on the court decision concerning the tax on the oil issue. Cornwell, however, also indicated, "he would be glad to" call for a special session on the matter of woman suffrage alone, "if a majority of the members of the Legislature requested it." ${ }^{37}$ Hence Yost's early communication with lawmakers before the Governor called the session.

Governor Cornwell also wanted to be prepared in case he was required to call the session for the suffrage cause only. He wrote to Yost, "I do feel that the safest thing to do is to get the majority of the members in writing on this subject," otherwise, "if [a special session] has to be called for the suffrage amendment especially, I am unwilling to take any chance and do not think you should." 38

\footnotetext{
${ }^{35}$ Harmer to Yost, 1 August, 1919, Yost Papers, ADD Box 1.

${ }^{36}$ McCauley to Yost, 13 February, 1920, Yost Papers, ADD Box 2.

${ }^{37}$ Yost to Baker, 23 January, 1920, Yost Papers, ADD Box 2.

${ }^{38}$ Cornwell to Yost, 12 January, 1920, Cornwell Papers, Box 86.
} 
Although Yost longed for the vote, she also demonstrated her political acumen. She knew that she had to recognize the interests of her state as well. Yost's political goals incorporated a wide variety of different types of reform, not solely woman suffrage. Therefore, she decided to prepare herself, but at the same time remain informed about the best way to achieve her goal without hurting West Virginia. Yost wrote to Carrie Chapman Catt, "I have had several conferences with politician members of our State Advisory Board and, without exception, they consider the situation in West Virginia one that needs more careful handling. I do not want to make a bad move at this time." Yost knew that the gas and oil situation in the courts would cause hesitation among some members of the legislature in signing a petition for the special session. And since she needed three-fifths of the members of the legislation to sign a petition, she leaned towards waiting as long as she could before lobbying for signatures. ${ }^{39}$ This display of caution and sound judgment contributed to Yost's ability to insert the right amount of pressure upon lawmakers when decisive situations called upon her experience.

Lenna Yost found herself under pressure from both sides. On one hand, NAWSA's president Carrie Chapman Catt was pushing for a special session to be called right away in West Virginia. Other members of the legislature were also concerned that the session could not wait any longer. A letter from the West Virginia National Republican Committeeman, V.L Highland, urged her to start the petition right away and not to wait on the gas and oil case. ${ }^{40}$ Yost knew that the suffrage situation in West Virginia had to be resolved as soon as possible. On the other hand,

\footnotetext{
${ }^{39}$ Yost to Catt, 19 January, 1920, Yost Papers, ADD Box 1.

${ }^{40}$ Highland to Yost, 20 January, 1920, Yost Papers, ADD Box 2.
} 
as a politically minded activist, she understood the financial implications to West Virginians of calling two special sessions in one year. Therefore, she was sympathetic to the governor's decision to wait as well. On July 25,1919 , she wrote to the Governor that she understood it "would be unfortunate to have several special sessions of the legislature in one year." Furthermore, she appreciated his "disposition to postpone a decision in regard to the time to call a session." 41 In an interview she gave January 30,1920, regarding whether or not the Governor was going to call a special session, she stated, "We are entirely satisfied with the Governor's position." 42

Although Carrie Chapman Catt leaned on Lenna Yost to direct the situation in West Virginia, she was well aware of the Governor's position. On December 29, 1919, Catt decided to communicate with Cornwell herself, asking him to go public with his intention to call a special session. The fact that the six governors from Wyoming, Nevada, Arizona, Indiana, Delaware and West Virginia had communicated with each other of their desire to call for a special session but had not yet agreed to make their decision public frustrated Catt. Not only was this condition hurting the suffrage cause, according to Catt, but other states were also waiting on the ratification due to their desire to be last state needed to ratify the amendment. This situation needed to be resolved, and she was hoping Governor Cornwell would come through with the special session once he received her letter and understood the importance of his decision. ${ }^{43}$

\footnotetext{
${ }^{41}$ Yost to Cornwell, 25 July, 1919, Cornwell Papers, Box 86.

42 “Suffrage Leader Sure Women Will Get the Vote,” The Charleston Daily Mail, 30 January, 1920.

${ }^{43}$ Catt to Cornwell, 29 December, 1919, Cornwell Papers, Box 86.
} 
In the History Of Women Suffrage, Ida Husted Harper, probably not aware of the full sequence of events, implied that Catt's letter to the Governor must have influenced his decision in calling the special session for February 27, even though Cornwell did not call the session until more than a month after receiving Catt's letter. Harper did not mention Yost's influence or contributions in achieving the special session. ${ }^{44}$ Nor did Carrie Chapman Catt, who mentioned the letter she had sent to the Governor in Woman Suffrage and Politics. ${ }^{45}$ However, the sequence of events ignores the savvy of Lenna Yost. Cornwell wrote Catt on January 6, 1920, explaining his dilemma, stating that he would not call the special session right away, but he would wait on the oil situation. Moreover, if he were to call the session on the matter of suffrage only, he "would be doing it in the face of an adverse vote of nearly one hundred thousand as registered at the election of $1916 . " 46$

What Catt did not know was that, when Lenna Yost became aware of the letter Catt had sent to the Governor, Yost sent an emergency telegram to Cornwell, which asked, “will you kindly defer answering Mrs. Catt's letter until mine reaches you." ${ }^{77}$ In Yost's letter of December 31, 1919, she wrote, "If for any reason you feel it would be better to delay West Virginia's special session until early in February, our state's Committee will not have in their hearts to remonstrate, for I think we appreciate the advantage of having possible other needed legislation combined with the call." 48 Cornwell wrote Yost that he had explained to Catt, "I do not feel justified

\footnotetext{
${ }^{44}$ Ida Husted Harper, History of Woman Suffrage, Volume VI (New York, NY: J.J Little \&Ives Company, 1922), 694.

${ }^{45}$ Catt, Woman Suffrage And Politics, 392.

${ }^{46}$ Cornwell to Catt, 6 January, 1920, Cornwell Papers, Box 86.

${ }^{47}$ Yost to Cornwell, 31 December, 1919, Cornwell Papers, Box 85.

${ }^{48}$ Yost to Cornwell, 31 December, 1919, Cornwell Papers, Box 85.
} 
in precipitating a special session for the consideration of the suffrage amendment alone unless a majority of the members of the legislature pledged to me their support of the amendment and indicate a desire for the legislature to be called together." Six days later, he requested that Yost be responsible for getting the members of the legislature to sign a petition for a special session. ${ }^{49}$

There was pressure for the remaining states to ratify the amendment before the voter registration deadline for the presidential primaries of 1920. Suffragists wanted the earliest date possible so that newly enfranchised women would be able to participate in the primaries in West Virginia. Yost had learned that the earliest presidential primaries for the 1920 election would not occur until the month of March. Yost concluded, "Ratification by thirty-six states should be accomplished in good time for the women to register for the primary." 50 Therefore, she was willing to support the Governor and wait a little longer on the gas and oil company court ruling.

Lenna Yost was very much involved in the Governor's decision to hold the special session, understanding the need for Cornwell to solve both problems. In a letter addressed to Hon. C.L. Shaver on January 29, 1920, who corresponded regularly with Yost, Cornwell affirmed Yost's support of his decision. On January 23, 1920, Shaver had pressured the Governor not to wait on the court decision, stating that West Virginia could not "afford to delay it much longer." 51 The Governor responded by mentioning that Yost had spent the night at his house discussing

\footnotetext{
${ }^{49}$ Cornwell to Yost, 6 January, 1920, Cornwell Papers, Box 86.

${ }^{50}$ Yost to Cornwell, 31 December, 1919, Cornwell Papers, Box 85.

${ }^{51}$ Shaver to Cornwell, 22 January, 1920, Cornwell Papers, Box 86.
} 
suffrage matters and that she confided to him that only twenty seven states had ratified the amendment. Yost was not fully certain that the rest could be obtained in so little time. Therefore, it was not necessary that the Governor rush in the calling of the special session. According to the Governor, Yost was "entirely satisfied with this." 52

Governor Cornwell was personally in favor of women suffrage, but the issue involved a substantial degree of partisan politics. Being a Democratic Governor, Cornwell was under pressure from his peers to do what was best for his party. In a letter addressed to Colonel J. H. Crosier on February 19, 1920, Cornwell made clear the consequences of not calling the session in support of the suffrage amendment. According to the Governor, failing to support the session would result in a victory for the Republicans, since "the Republicans are preparing to have the Republican members do it by petition so as to be able to say to the women of the State that a Democratic Governor had sought to prevent their voting." 53

In the meantime, Governor Cornwell expected Yost to persuade the majority of the legislators to vote in favor of the suffrage amendment. Yost continued to organize petitions and prepare suffrage advocates in case the special session was indeed called. Her strategies early on and throughout the defining moments of the ratification process included pressuring undecided West Virginia lawmakers. Yost wrote to Catt, "The doubtful members of the our legislation have been assigned to influential politicians who are for suffrage;" "In addition to this, women in every

\footnotetext{
${ }^{52}$ Cornwell to Shaver, 5 February, 1920, Cornwell Papers, Box 86.

${ }^{53}$ Cornwell to Crosier, 19 February, 1920, Cornwell Papers, Box 86.
} 
community where there is a doubtful member, with the exception of two or three, are to wait upon them within the week."54

Cornwell asked for regular updates on the number of states that were willing to ratify the amendment, the progress made with the legislators and the deadline for calling West Virginia's special session. His letters to Yost contained requests such as "would you mind advising me just how many definite pledges you have on this proposition?" 55 Clearly, Yost had to remain involved with the legislators from her state and keep up with federal requirements every step of the way. Moreover, Yost pressured the various women organizations of her state to support the suffrage amendment, noting that, "We have sent out letters to all the state presidents of Women's Organizations, asking them to go on our State Committee." 56 Yost also informed the Governor that it would be wise to call the session before February 20 . According to her, telegrams and letters she received regarding the possibility of West Virginia not being included in the thirty six states that ratified the amendment convinced her that, if he did not call the session before then, her committee would be unable to keep the public from signing a petition, and creating unnecessary agitation. ${ }^{57}$

On February 20, 1920, Governor Cornwell announced that he was calling the special session of the legislature for February 27, 1920, to discuss several matters, one of them being the woman suffrage amendment. ${ }^{58}$ Suffrage supporters' hope of

\footnotetext{
54 Yost to Catt, 24 September, 1919, Yost Papers, ADD Box 1.

${ }^{55}$ Cornwell to Yost, 23 January, 1920, Yost Papers, ADD Box 1.

${ }^{56}$ Yost to Catt, 24 September, 1919, Yost Papers, ADD Box 1.

${ }^{57}$ Yost to Cornwell, 11 February, 1920, Yost Papers, ADD Box 1.

${ }^{58}$ Cornwell to West Virginia Executive Committee, 19 February, 1920, Cornwell Papers, Box 87.
} 
becoming one of the thirty-six was close to becoming a reality. The call was all over the news, and according to the Wheeling Register, the announcement was shocking, since everyone was expecting that he was going to take action on the suffrage question later that year. ${ }^{59}$ In a letter addressed to the West Virginia Executive Committee on February 19, 1920, Cornwell explained his reasons for calling the special session. According to the Governor, the number of states needed to ratify the amendment was narrowing down, "consequently, the women will be permitted to vote at the fall elections, even if this state should fail to act." Therefore, "appropriate legislation should be enacted immediately to enable the women to participate in the primaries." ${ }^{60}$ Cornwell also feared that, if other states ratified the amendment before West Virginia, the women of his state would be granted the right to vote by men from other states.

Upon learning of the Governor's decision, several West Virginia politicians expressed their gratitude and acknowledged, through letters and telegrams, the work Lenna Lowe Yost had provided to the cause. "I certainly congratulate you on your long and trying efforts in this behalf," said the Speaker of the House of Delegates, J. L. Wolf. United States Senator Davis Elkins also congratulated Yost on the crucial leadership role she "played in bringing this issue to the point of decision in our state." ${ }^{61}$ Moreover, House of Representatives member George M. Bowers sent Yost a letter on February 23, 1920, acknowledging her for the "splendid service" she

\footnotetext{
59 The Wheeling Register, 20 February 1920.

${ }^{60}$ Cornwell to West Virginia Executive Department, 19 February, 1920, Cornwell Papers, Box 87.

${ }^{61}$ Elkins to Yost, 20 February, 1920, Yost Papers, ADD Box 2.
} 
had provided, emphasizing that he trusted her work would "be crowned with overwhelming success." 62

Now that the special session had been called, the battle for the votes began. Yost wanted to create the necessary pressure from various strategic points. She had ample experience with the 1916 state referendum campaign and with the prohibition movement in the country. On February 21, only a day after the Governor called the special session, she sent a letter to the members of the Advisory Committee, urging them to send telegrams to the members of the State Senate and House of Delegates. According to Yost, "these messages will bring to the Legislature as a body an influence we think is important," since lawmakers valued the support of people of influence. ${ }^{63}$ She also requested their presence at the Capitol immediately. Yost continued to seek the support of the state's U.S. Congressional delegation for the amendment. Lawyer R. Dunlap was impressed by Yost's skills. On March 8, 1920, while the Senate was still in session, he admiringly wrote, "With best wishes for you and the cause you are so admirably championing."64

Many, including Yost and the major suffrage organizations, felt confident that West Virginia would ratify the amendment. The day after Governor Cornwell called the special session of the legislature, The Clarksburg Telegram asserted that, "immediate ratification with as near unanimous consent as possible, and with as little show of opposition as possible from anyone." 65 George E. White, an attorney,

\footnotetext{
${ }^{62}$ Bowers to Yost, 23 February, 1920, Yost Papers, ADD Box 2.

${ }^{63}$ Yost to the ratification Committee, 21 February, 1920, Yost Papers, ADD Box 2.

${ }^{64}$ Dunlap to Yost, 8 March, 1920, Yost papers, ADD Box 2.

65 "Immediate Ratification of Suffrage question is Expected,” The Clarksburg Daily Telegram, 21 February 1920.
} 
assured Yost on February 23, that "there will be no difficulty as to its passage."66 The NWP also included West Virginia among the states that were sure to ratify. Mary Dubrow wrote for the Suffragist, the Party's newspaper: "As I left for West Virginia I confided to every one I met how happy I was to go to a State which would probably ratify unanimously." 67 The New York Times had previously reported on February 19, 1920, "a recent poll among the members of the legislature showed the sentiment to be strongly in favor of the amendment." 68

Nevertheless, suffrage supporters faced a wave of opposition coming from all parts of the country. Opponents invaded West Virginia in an attempt to stop the amendment. On February 24, U.S. Senator Howard Sutherland informed Yost about opposition coming their way from Maryland, urging her to "see that they get warm reception." ${ }^{69}$ Letters poured into the Governor's office from anti-suffragists. On February 26, 1920, the day before the special session was to open, Cornwell received the following telegram: "Committee appointed by Maryland Legislature leaving tonight for your state to urge westva legislature to vote against suffrage." 70 Anti-suffragists' main argument focused on the debate between the rights of the federal government versus those reserved for the states, and the fact that northerners were once more violating southerners' rights. Some anti-suffragists asserted they were not against a woman's right to vote; they simply wanted to ensure that each state, not the federal government, made its own decision regarding

\footnotetext{
${ }^{66}$ White to Yost, 23 February, 1920, Yost Papers, ADD Box 2.

${ }^{67}$ Inez Haynes Irwin, The Story of Alice Paul, And The National Woman's Party (Fairfax, Virginia: Denlinger's Publishers, LTD, 1964), 452.

68 “New Mexico Votes Suffrage, West Virginia acts next week," The New York Times, 20 February $1920,1$.

${ }^{69}$ Sutherland to Yost, 24 February, 1920, Yost Papers, ADD Box 2.

${ }^{70}$ Baltimore Sun to Cornwell, 26, February, 1920, Cornwell Papers, Box 87.
} 
the issue. "I therefore respectfully and earnestly beg you in mercy to the States of the black belt to recommend to the Legislature of the State of West Virginia that if they desire suffrage for their own women to grant it by state action."71 Many southerners held strong sentiments such as, “Can't you realize that the enforcement of the Woman Suffrage Amendment means the enforcement of the $15^{\text {th }}$ Amendment through out the south?" The Fifteenth Amendment had been passed in 1870, as a Reconstruction measure. It stated, "Governments in the United States may not prevent a citizen from voting because of his race, color, or previous condition of servitude." 72 Politicians in the South not only feared that the black vote would enhance Republican Party influence throughout the country, but also that black women would gain power through woman suffrage and use it to promote the African American cause. To the supporters of black disfranchisement, granting suffrage to black women represented a setback. By linking woman suffrage to issues of racial equality, anti-suffragists sought to create dissention within the movement.

Once more, Yost faced a new and unexpected challenge. She urged the members of the legislature to come to Charleston promptly to fight the opposition. Some took the request seriously; others, such as L.S. Echols from the House of Representatives in Washington D.C, acknowledged the request from Yost, but answered that he was not going to able to make it in time. He assured her, however, that the opposition from Maryland "could not possibly have any influence" upon the West Virginia legislature. Later, after the amendment was ratified in West Virginia, supporters of the cause acknowledged the unexpected wave of opposition that

\footnotetext{
${ }^{71}$ Brown to Cornwell, 20 February, 1920, Cornwell Papers, Box 87.

${ }^{72}$ Brown to Cornwell, 20 February, 1920, Cornwell Papers, Box 87.
} 
surfaced in the state. As they remembered, "The opposition which came so suddenly, was in the first place national and was exceedingly bitter from this source, possibly because of the approaching nearness of the success of the movement, and anti- suffrage leaders from all over the United States appeared as if by magic."73

Members of the legislature convened on February 27 to discuss seven possible legislative acts, including woman suffrage. In the Executive Department Proclamation of the special session by the Governor, the fifth item was: "To consider and to ratify the Amendment to the Constitution of the United States, extending the right of suffrage to women and to pass all appropriate legislation making the same effective in West Virginia for all purposes." ${ }^{74}$ Some Democrats, such as Senator Herman Guy Kump, voted for suffrage in support of their Democratic Governor even though they were not in favor of the amendment. On March 2, Kump told the New Dominion that, although back in 1916, his district voted against suffrage, "the Governor has asked his friends to vote for the amendment and he was doing so." The opposition, such as Senator Luther, replied to that same edition, "a woman's place was in her home and he was attempting to protect woman from herself." The main argument anti-suffrage senators used was the fact that the state referendum for suffrage was defeated by too large a margin back in the 1916, and they wanted to respect the wishes of those who voted and trusted them in office. ${ }^{75}$

\footnotetext{
${ }^{73}$ Unknown to Catt, 10 March, 1920, Yost Papers, ADD Box 1.

74 “Executive Department, A Proclamation By The Governor,” 20 February, 1920 (undated typescript), Cornwell Papers, Box 87.

${ }^{75}$ Initial vote on Ratification of Equal Suffrage Amendment in State Senate A Deadlock,” The New Dominion, 2 March 1920.
} 
The West Virginia House ratified the amendment by a majority of 47 to 40 on March 3, 1920, while the senate vote tied 14 to 14 . This tie in the senate represented a problem for suffragists. Both sides seemed to have very strong convictions about their decision and were not willing to change their votes. If the issue of suffrage remained unresolved and the special session ended, consideration of a woman suffrage amendment would have to wait until the next session of the legislature.

As the days passed with the senate deadlocked, some women's activists lost faith that the amendment would pass. The situation in West Virginia seemed to reach a point of desperation for the suffragists. "Conservative members of both sides think the amendment is lost," the New York Times claimed on March 1.76 On March 2, the New York Times published an article alleging that the suffrage cause had lost in West Virginia. It stated that Democratic President Woodrow Wilson asked antisuffrage senators Burr and Frazier to change their vote, but they declined the President's request. ${ }^{77}$ Yost stated, "our temporary defeat in the State Senate was not the result of a majority of the senators being opposed to equal suffrage."78

On March 1, 1920, one of the principal advocates of the suffrage amendment, Harrison County's Senator Harvey Harmer, managed to come up with an immediate solution, hoping suffragists would develop a new strategy soon. Harmer changed his vote to "no" for suffrage, enabling reconsideration of the amendment and forcing the

\footnotetext{
76 "West Virginia Senate beats Suffrage; House also hostile to the Amendment,” New York Times, 2 March $1920,1$.

77 "Suffrage Killed in West Virginia: House Approves Ratification, But Senators Reject Wilson's Plea and Refuse to Reconsider. Cannot Be Called up Again Only Eight left from Which to Obtain Three Needed ratifications," New York Times, 4 March 1920, 1.

78 "Resume Given by Mrs. Yost," 4 March, 1920, Yost Papers, ADD Box 2.
} 
Senate to adjourn and reconsider at a later time. ${ }^{79}$ On March 2, 1920, The Wheeling Intelligencer reported, "With Suffrage beaten on tie vote, Harmer changes vote so as to enable reconsideration." ${ }^{80}$ However, on March 3, "the vote to reconsider stood 14 to $14 . " 81$ The suffrage cause needed one more vote. Yost and the suffragists ardently battled to break the tie in the Senate. Since a majority of the members of the legislature had to agree to adjourn in order for the session to end, suffragists had time to come up with a solution. West Virginia senator Jesse Bloch was vacationing in California at the time of the special session. Speculation existed that he had gone there to avoid the suffrage question. Bloch denied that allegation later to the New Dominion, confirming that he had always been for suffrage. Bloch's vote was the most obvious solution to the problem. According to The Wheeling Intelligencer, "The plan is to hold the senate in session by means of the fourteenth suffrage votes in preventing final adjournment until Senator Bloch returns." 82 The New York Times reported, "Senator Bloch appears to hold the fate of suffrage in West Virginia in the hollow of his hands." 83 The climactic travel across country senator Bloch made was in the front page of every local newspaper at the time.

As the possibility of Senator Bloch coming back to West Virginia surfaced in the news, those opposed to suffrage were trying to kill the amendment before Bloch decided to make his way back to the state. According to Senator Wallace B. Gribble,

\footnotetext{
${ }^{79}$ Irwin, The Story of Alice Paul, And The National Woman's Party, 452.

80 “Suffrage Meets Reverse Senate; Kuykendall Puts in Resolution for Referendum,” The Wheeling Intelligencer, 2 March 1920.

81 “Senate’s Tie Vote Kills Suffrage AT This Session; House Votes for Ratification,” The Wheeling Intelligencer, 4 March 1920.

82 “Senator Bloch on His Way to Charleston' Will Cast Vote in Favor of Votes for Women,” The Wheeling Intelligencer, 5 March 1920.

83 “Women Will Hold GOP Responsible,” The New York Times, 5 March 1920, 17.
} 
Bloch "had ample time to reach Charleston long before" the special session. Gribble also asserted that, because of Bloch, the Senate was spending a lot of money keeping lawmakers in session, waiting for his return. ${ }^{84}$ The idea was to pressure West Virginians to resent the amendment, since they were the ones paying for the Senate to remain in session. Bloch then requested his vote be paired, so he did not have to make the trip back to Charleston. Pairing represents an alternative way for senators to cast their vote. "They may announce a pair with another lawmaker; each declares his or her position on the pending matter, one for and the other against, but neither is actually present to vote." Senators may also choose to pair with one member not present and with the other member having the opposite point of view. In this case, the member present, with the opposing view, agrees not to vote. ${ }^{85}$ However, the opposition refused Bloch's request.

After the anti-suffrage senators refused to pair Bloch's vote, according to Yost, Jesse V. Sullivan, a local newsman, and Houston G. Young, a personal friend of Senator Bloch, telephoned him and urged him to come back. ${ }^{86}$ Later, other organizations, such as the NWP and the Republican Committee from West Virginia, gave different reports about who had made contact with the senator first. In a very disappointed letter Yost sent to Ida B. Harper, she claimed that "The National Republican Committee did not pay for the special train." ${ }^{87}$ Although Yost was a Republican herself, she criticized the false claim. She took pains to ensure that the

\footnotetext{
84 "Suffrage Will Be Ratified on Arrival Of Senator Bloch from West; Legislature Adjourns until Monday," The New Dominion, 6 March 1920.

${ }^{85}$ Leroy N. Rielselbach, Congressional Politics, the Evolving Legislative System (Westview Press, 1995), 122.

${ }^{86}$ Harper, History Of Woman Suffrage, Volume VI, 695

${ }^{87}$ Yost to Harper, 1921 (undated typescript), Yost Papers, ADD Box 2.
} 
appropriate people got the appreciation they deserved. Yost also made it clear that a large amount of the expenses to bring Senator Bloch back in time for the session were paid by someone who had chosen to remain anonymous. ${ }^{88}$ Later, it was known that Captain Victor Heinze of Cincinnati had provided Bloch with the special train so that he could arrive in time to decide the amendment in West Virginia. ${ }^{89}$ The situation was so tense that suffragists were accusing anti-suffragists of plotting to kidnap Senator Bloch. On March 7, The Wheeling Daily News reported that the exact location of Bloch's progress across country was being kept a secret for fear of a kidnapping. ${ }^{90}$

In the same letter, Yost bristled that the NWP was claiming credit for Bloch's return. She mentioned that the NWP had nothing to do with bringing the Senator back, even though a picture of the members of the NWP with the senator appeared in the Suffragist on the day of Bloch's arrival. Moreover, she stated that, "no one who was on the ground would give credit to the Woman's Party in the Campaign."91 According to Yost, the NWP members "asked to have their pictures taken with Senator Bloch a few minutes after the Fox Film Company's agent had taken pictures for movies." 92 Yost also stated that Fox was there with the intent of taking a picture of her with the pro-suffrage West Virginia senators. Despite Yost's efforts, Ida Harper's The History of Woman Suffrage did not acknowledge Yost's contribution to

\footnotetext{
${ }^{88}$ Yost to Harper, 1921 (undated typescript), Yost Papers, ADD Box 2.

${ }^{89}$ Harper, History Of Woman Suffrage, 695.

90 "Woman say Antis Might Kidnap Sen. Bloch, Ballot Hope,” The wheeling Daily News, 7 March 1920.

${ }^{91}$ Yost to Harper, 1921 (undated typescript), Yost Papers, ADD Box 2.

92 Yost to Harper, 1921 (undated typescript), Yost papers, ADD Box 2.
} 
Bloch's return. Harper only mentions the efforts of Houston G. Young, omitting the fact that Yost was involved in the process.

After Bloch's arrival, the opposition had one more card to play. Senator A.R. Montgomery had resigned on June 17, 1919, to move to Illinois and enter into personal business. ${ }^{93}$ When the situation heated up in West Virginia eight months later, Montgomery returned from Illinois to try to regain his seat in the senate. He requested that Cornwell disregard the letter and let him participate in the voting process. The senator was against the suffrage amendment; therefore, his vote would tie that of Senator Bloch, probably causing the defeat of the amendment in West Virginia. Anti-suffragists saw this as an opportunity to cause more agitation in Charleston. Governor Cornwell rushed and submitted Montgomery's letter of resignation on March 10, 1920 during the extraordinary session of the senate. Because the letter was in fact legitimate and it had already been processed, the Senate did not allow Montgomery to take his seat, denying his request to vote. ${ }^{94}$ The final vote occurred on March 10, 1920, with sixteen for the amendment and thirteen against. Senator Burr had changed his vote when he realized that the Senate would go in favor of the amendment. According to the Clarksburg Exponent, the suffrage voting in West Virginia was "the one of the most dramatic sessions ever witnessed in either House." 95 After an incredible effort from suffragists all around the nation, the ratification of the Nineteenth Amendment granting women the vote was

\footnotetext{
${ }^{93}$ Montgomery to Cornwell, 10 March, 1920, Cornwell Papers, Box 87.

${ }^{94}$ Harper, History of Woman Suffrage, 695.

95 "Senator Bloch Casts Deciding Vote After Exciting Home Trip," The Clarksburg Exponent, 11 March 1920.
} 
completed on August 18, 1920, when Washington and Tennessee voted in favor of ratification.

Although the extent of Yost's participation in keeping the senators in Charleston waiting for Bloch's arrival is unclear, and not mentioned in the histories of woman suffrage, telegrams that poured into Yost's office, congratulating her for the victory in West Virginia, are evidence of her indispensable contribution. "Our progressive citizens applaud your victory and extend congratulation," claimed R. F. Dunlap. Alan H. Robinson, an Ohio county judge, wrote to Yost on March 11 that, "You, especially, have worked hard and earnestly in behalf of the cause, and the victory is deservedly and well earned." 96 One article reported, "Mrs. Ellis Yost, leader in the fight for suffrage in West Virginia, is a small woman but indefatigable in determination, and it was through her direction and hard work that the suffragists made such an excellent showing," 97 Yost was also very careful to include the names of those she believed were instrumental to victory; in her public statement on March 16, she credited the victory to Julia Ruhl, president of the WVESA and the members of the Ratification Committee in West Virginia. ${ }^{98}$ Moreover, at Ida Husted Harper's request, Yost gave the names of the people who were on the ground fighting alongside her when the suffrage cause seemed to be lost in West Virginia. Yost credited "Elliot Northcott (former minister of Venezuela); Jesse V. Sullivan, Albert B. White, a former Governor of West Virginia; W.E. Baker; Grant P. Hall, mayor of Charleston; Houston G. Young; W.E. Chilton, former United

\footnotetext{
${ }^{96}$ Robinson to Yost, 11 March, 1920, Yost Papers, ADD Box 2.

97 "Legislature Sidelights," (undated typescript), 1920, Yost Papers, ADD Box 2.

${ }^{98}$ Yost to Harper, 1921 (undated typescript), Yost Papers, ADD Box 2.
} 
States Senator; Fred O. Blue, former State Tax Commissioner; Clyde B. Johnson, attorney," and Governor Cornwell as those working with her. ${ }^{99}$

According to militant suffragist Alice Paul, woman suffrage was "a 'purely feminist' program on which women could unite regardless of their disagreements on other issues." 100 That was not the case. Major suffrage organizations were constantly fighting for the spotlight and criticizing one another. Disagreements over strategies occurred between different groups and within an organization as well, often hindering the movement. The quality of leadership, such as Yost displayed in West Virginia, allowed for collaboration and made a difference in the final steps in the ratification of the Susan B. Anthony Amendment.

Moreover, prominent national leaders are the ones usually recognized for the major accomplishments. The suffrage movement in West Virginia proved that the struggles local communities experienced and the work of their faithful servants, such as Lenna Yost, often went unnoticed. The successes of local movements highlight the importance of the will of the people that benefit from a federal government decision, such as woman suffrage, to continue the fight for their rights in their own states. These, as well as innumerable other contributing factors, render some decisions capable of being the catalyst to major change, while others fade through time.

Lenna Lowe Yost continued to fight for woman's rights everywhere long after the suffrage battle was won. She remained active in the Union Signal, writing articles on prohibition and other issues concerning politics, women, and children. She also

\footnotetext{
${ }^{99}$ Yost to Harper, 1921 (undated typescript), Yost Papers, ADD Box 2.

${ }^{100}$ Cott, The Grounding Of Modern Feminism , 71.
} 
continued to be engaged in politics within her state and worked tirelessly to improve conditions for women in West Virginia. One example of this is represented by Elizabeth Moore Hall at West Virginia University. One would think that a person with such great influence would be recognized and mentioned more often in the history of the accomplishments women made in the United States. It is surprising and unfortunate that so little is known about her and the other extraordinary women who worked diligently to achieve suffrage in West Virginia.

Surprisingly, even though Yost was deeply involved in the victory, she did not write her own accounts of the woman suffrage movement in West Virginia. Although Yost did not explain the reasoning behind her silence, she was clearly offended at some point with how others chose to tell the story at the time. In a letter, Carrie Chapman Catt, seemingly responding to Yost's criticisms, asked for time to answer a few questions Yost had asked. Catt added, "If, however, there was any hiatus in letters, or telegraphic communications from this office, which led you to believe that we were for a single moment unmindful of the terrible strain under which you were laboring, that we did not appreciate your conscientious purpose, and were not grateful for all you were doing and did, allow me now to set your heart at rest on this score." 101

However, those who worked closely with Yost understood the extent of her work and ardently praised her dedication to advancing progressive causes. After the suffrage battle was won in West Virginia, Carrie Chapman Catt received a letter from the prominent politicians and supporters of the movement within the state,

\footnotetext{
${ }^{101}$ Catt to Yost, 22 March, 1920, Yost Papers, ADD Box 1.
} 
acknowledging Yost's leadership and essential contribution to the suffrage cause. "Suddenly and unexpectedly, as Mrs. Yost was, by opposition, when it seemed that ratification would go through overwhelmingly, Mrs. Yost handling of the situation, as leader in the fight, has been in our judgment, remarkably able." They added, "The opposing elements combined tended to create for Mrs. Yost what at first seemed to be a situation impossible of solution, but with rare tact and a soundness of judgment that we have seldom seen equaled her leadership has brought about a complete victory." 102

${ }^{102}$ Unknown to Catt, 10 March, 1920, Yost Papers, Box 1. 


\section{Chapter 5: Conclusion}

After the ratification of the nineteenth amendment, women redirected their efforts toward other social and political reforms. Consequently, the suffrage victory brought about a split in the women's movement, as well. Alice Paul, for example, eagerly campaigned for the Equal Rights Amendment (ERA), while Carrie Chapman Catt worked towards reorganizing the National American Women Suffrage Association (NAWSA) into the League of Women Voters (LWV). In their fight for equal rights only, the National Woman's Party (NWP) clashed with the principles of protective legislation for women, which many working class women advocated for, generating animosity between those two groups. Harriot Stanton Blatch focused on educating women in politics, encouraging them to join political parties, openly challenge lawmakers, and lobby senators for the legislative actions they believed necessary. ${ }^{1}$ Other former woman suffrage advocates on the other hand, due to their belief that women were moral reformers, did not want to be involved in party politics and maintained a non-partisan position in the "corrupt" political arena.

Like many reformers of her time, Lenna Lowe Yost's dedication to women's causes did not end with the triumph of prohibition and woman suffrage. With the victories Yost achieved as head of both the temperance and suffrage movements in West Virginia, and her subsequent participation in the many affairs concerning women and children, she proved herself an extraordinary leader. As The Herald

\footnotetext{
${ }^{1}$ Ellen Carol Dubois, Harriot Stanton Blatch And The Winning Of Women Suffrage (New Haven and London: Yale University Press, 1997), 125.
} 
Dispatch noted, "There is not an issue affecting the welfare of West Virginians in which her leadership has failed her constituency." ${ }^{2}$

Upon the ratification of the Susan B. Anthony amendment, Yost joined a group of activists who supported women's full participation in party politics. According to Yost, "The science of politics is the intelligent comprehension of one's position and relations as member of a great nation." 3 She ardently advocated for women to join a political party, encouraging them to work for reforms through the party of their choice. Immediately upon moving into the political arena, Yost began tearing barriers that had previously prevented women from holding important positions in government agencies and political parties. While writing for the Union Signal in the 1920s, she educated Americans on a variety of reforms needed in order to strengthen the nation's democratic principles, such as controversial bills, wars, child labor laws, and women's rights. As member of the Republican Party, the W.Va. State Board of Education, and other organizations, she helped pass legislation that improved West Virginia's schools, aided on the establishment of the juvenile court, and educated women on political issues. ${ }^{4}$

In 1920, Chicago, Lenna Yost became the first woman to serve as counting teller in a National Republican Convention. In 1921, West Virginia Governor Ephraim F. Morgan appointed Yost, then Morgantown associate chair of the Republican Executive Committee, to the West Virginia Board of Education; she became the first woman to be appointed to a statewide office. She held this position

\footnotetext{
2 Jim Clendenin, “Carry On,” 25 May, 1932, Yost Papers, Box 3.

${ }^{3}$ Lenna Yost, “Independent Woman," (undated typescript), Yost Papers, Box 3.

${ }^{4}$ Martha Brock, ("Mrs. Ellis A.) Lenna Lowe Yost," (undated typescript), Yost Papers, Box 3.
} 
for twelve years. ${ }^{5}$ As member of the State Board of Education, one of Yost's most ardent missions consisted of improving women's education in colleges in order to meet the American Association of University Women (AAUW)'s requirements for membership for women to join the AAWW. She wrote to Mrs. Ella Lonn, "As a member of the state board of education of West Virginia for seven years I have been deeply interested in bringing our University and colleges up to the standard which will qualify them for membership in the AAUW Our struggle now is for Wesleyan and Marshall Colleges." 6 Yost visited schools and universities promoting, "1.Physical fitness; 2.Mental fitness, which would enable one to see and think clearly; 3. Vocational fitness, which was designed to bring to all the joy of service; 4 . Moral fitness, which is necessary in perpetuating the traditions of American institutions." 7

In 1921, President William Harding appointed Yost as one of the nine delegates to represent the United States at the International Congress against Alcoholism in Lausanne, Switzerland. That same year, in the midst of his wife's unique accomplishments, Ellis Yost was working as deputy state tax commissioner in West Virginia. Then, in 1922, he became the United States attorney for the Southern District of West Virginia. In 1923, President Harding called upon Lenna Yost again, appointing her as a delegate from the United States for another Congress on Alcoholism, this time in Copenhagen, Denmark. ${ }^{8}$

\footnotetext{
5 "Mrs. Lenna Yost is Given Place on the State Board of Education,” 12 May, 1921, Yost Papers, Box 2.

${ }^{6}$ Yost to Lonn, 29 May, 1919, Yost Papers, Box 2.

7 “Mrs. Yost Addresses Collegiate Institute," (undated typescript), Yost Papers, Box 3.

8 "Special appointments," (undated typescript), Yost Papers, Box 2.
} 
Throughout their lives, Lenna and Ellis Yost kept notably close contact with the White House and maintained a special relationship with several United States presidents, including Herbert Hoover and Dwight Eisenhower. Ellis Yost composed poems to honor presidents and the First ladies on numerous occasions. The Yosts were guests at several White House events, including formal balls and presidential inaugurations.

Lenna and Ellis Yost's son, Leland Yost, established a noteworthy career as well. Following his parents' example, Leland Yost received an excellent education at several respected institutions, including West Virginia University, the University of Michigan, Colorado University, and Columbia University. His accomplishments were also substantial. As a composer, he wrote a hit called "Twilight." Later, he worked as a law clerk for Elliot Northcott, as a U.S. circuit judge, and finally as a trial attorney. Continuing on the path laid out by his father, Leland Yost oversaw the Federal Communication Commission, including proceedings such as AM and FM licenses, and radio frequencies. He had one daughter, Lenna Lee. ${ }^{9}$

As a member of the State Board of Control and strong advocate of women's rights, Lenna Yost became deeply involved with the construction of the Elizabeth Moore Hall at the West Virginia University, initially slated to be named for Yost, who refused the honor. Yost envisioned a building strictly for female college students where they could feel comfortable while engaging in physical activities. Yost wrote to Commissioner John Tigert from the Department of the Interior, Department of Education in Washington DC that, "We are to have a new Women's Physical

\footnotetext{
9 “Biographical Data, Leland L. Yost,”(undated typescript), Yost Papers, Box 3.
} 
Education Building at the State University and as a Member of the Committee to plan for it, I am anxious to secure all possible information about such buildings at other institutions." 10 The University's President, John Trotter, requested Yost's presence to determine the location of the women's building, among other decisions concerning the hall. ${ }^{11}$ Architects involved in the project often inquired about Yost's preferences. For instance, one architect involved in the building queried Yost, "We have made details of the servery cabinets for the use of the contractor. ...If this is about what you would like to have, will you please let us know?"12 Yost chose most of the furniture for the building and pushed for its construction in 1925 more than anyone else involved in the project. ${ }^{13}$

Among her political advancements, Lenna Yost was the first woman to become a member of the Republican National Committee from West Virginia, an honor she held until 1932. She also became the first woman in the history of West Virginia to preside over a state convention, at her party's 1920 West Virginia meeting. ${ }^{14}$ Yost was the first woman chairman of any Republican State Convention and the first to act as chair of the Committee on Platform and Politics for the Republican State Convention in 1924.15 Moreover, she served as Chair of the State Federation of Women's Clubs in West Virginia.

She continued to be a fervent advocate for women to educate themselves in political matters, join a political party, and work toward achieving their political

\footnotetext{
${ }^{10}$ Yost to Tigert, 6 August, 1925, Yost Papers, Box 2.

11 Trotter to Yost, 12 July, 1926, Yost Papers, Box 2.

12 Dunlap and Barney to Yost, 22 July, 1927, Yost Papers, Box 2.

${ }^{13}$ Architects to Yost, 15 June, 1928, Yost Papers, Box 2.

14 “Republican Women's Organization,” (undated typescript), Yost Papers, ADD Box 2.

15 “Lenna Lowe Yost,” (undated typescript), Yost Papers, Box 3.
} 
goals within that party, while acknowledging the unique qualities they could contribute to the political realm. Yost stated, “Good men and good women don't give good government a better chance by getting out of political parties, but by getting into them with intelligence and courage." 16 She added, "Woman, I believe, is an important and wholesome factor in politics. Her natural instincts of loyalty to the things nearest to her heart make her a staunch supporter of her own beliefs, and an energetic partisan in this work." Yost believed women to be "endowed with special faculty for economy in management and efficiency in getting results," which were, "essential qualifications for success in politics as in homemaking." To Yost, women were "equipped with a modern education in statecraft and economics." 17 Yost asserted, "The new women voters are prepared to give to their country through a political party, a quality of service hitherto almost unknown." ${ }^{18}$ She believed politics to be the materialization of the reforms for which she advocated. ${ }^{19}$

Among other social reforms, Yost used her national recognition to promote the construction of the federal penitentiary for women at Alderson, Greenbrier County. ${ }^{20}$ "The Institution has been built on the lines of the best State reformatories for women." ${ }^{21}$ Superintendent Mary B. Harris requested Yost the honor of being one of the guest speakers. Harris wrote Yost, "Shortly after the address this afternoon there will be short speeches of felicitation from men and women who have been actively interested in the Institution and who played a part in its organization. I am

\footnotetext{
${ }^{16}$ Vylla Poe Wilson, “The Woman Political Leader Arrives,” (undated typescript), Yost Papers, Box 3.

${ }^{17}$ Ellen Orr, "Mrs. Yost is Strong for Women in Politics,” Yost Papers, Box 3.

${ }^{18}$ Mrs. Ellis A. Yost, "Republican Party Calls Young Women,” (undated typescript), Yost Papers, Box 3.

${ }^{19}$ Mrs. Ellis A. Yost, “Radio Address,” 22 September, 1932, Yost Papers, Box 3.

20 “Lenna Lowe Yost,” http://www.as.wvu.edu/engl01/users/students/rfigiel/public_html/yost.html

21 “Federal Industrial Institution for Women,” 24 November, 1928, Yost Papers, Box 2.
} 
counting on you as one of these two-minute speakers." ${ }^{22}$ Congressman Earl C.

Michener, who was involved in the project, wrote Julia Jaffray, chair, that, "I was pleased to assist in this matter and one could not forget the matter or neglect any duty in reference to it, as long as Mrs. Yost was interested, because we all recognize in Mrs. Yost a persistent legislative agent, yet not so persistent but that she is fairminded and reasonable, and therefore inspires confidence and a desire to help." ${ }^{23}$

In 1930, Lenna Yost became the director of the Women's Division of the Republican National Committee, a position she retained for five years. ${ }^{24}$ According to a memorandum on Yost's life, "In this position she received a salary comparable with salaries received by men in high executive position." ${ }^{25}$ That same year, President Herbert Hoover appointed Ellis Yost chief examiner for Federal Radio Commission, where he was praised for his work. ${ }^{26}$ From 1938 until 1949, Ellis Yost held the position of general manager for the Kentucky Producers Oil Company, and was also a member of the board of directors and Treasurer of the Gordon Oil Co. in Michigan. He passed away on January 7, 1962 in Washington, D.C. ${ }^{27}$ On his passing, in a letter Mamie Eisenhower wrote to Lenna Yost, she mentioned the lovely poems Ellis used to write to her and President Eisenhower. ${ }^{28}$

Women of the Progressive Era, such as Lenna Lowe Yost, who worked for women's and children's rights organizations, often found themselves divided when dealing with multiple reform issues. Sometimes referred to as the "Joan of Arc of

\footnotetext{
${ }^{22}$ Harris to Yost, 24 November, 1928, Yost Papers, Box 2.

${ }^{23}$ Michener to jaffray, 6 March, 1929, Yost Papers, Box 2.

24 “Lenna Lowe Yost L.H.D," 1934, Yost Papers, Box 1.

25 "Memorandun," (undated typescript), Yost Papers, Box 3.

${ }^{26}$ Medora Mason Wolfe, "Ellis Asby Yost,” March 1959, Yost Papers, Box 3.

27 "Ellis A. Yost," (undated typescript), Yost Papers, Box 1.

${ }^{28}$ Mrs. Dwight D. Eisenhower to Yost, 17 March, 1962, Yost Papers, Box 2
} 
West Virginia," Yost's ability to navigate through different ideologies and encourage collaboration, contributed to her success as a temperance worker, suffragist, reformer, and politician. ${ }^{29}$

Yost moved to northern Virginia as early as 1967. In 1971, she was living in the Hermitage Methodist Home in northern Virginia. First Lady Patricia Nixon wrote Yost, "It is indeed good to know that you are comfortably situated in the Hermitage and enjoying visits from your friends." 30 Lenna Lowe Yost passed away on May 1972, at age 94 . Several newspapers published obituaries on this extraordinary woman.

Those who had the honor to personally observe Lenna Yost's extraordinary achievements and dedication remembered her as a determined, well-spoken, capable individual. "She is a quiet, unaggressive, distinctly feminine type, but gifted with foresight and a determination to carry through," ${ }^{31}$ Anna Richardson observed. Martha Brock wrote in the Fairmont West Virginian, "Mrs. Yost has all the refinement and native delicacy of the traditional idea, with the clear sighted discernment, steady poise, and workable, dependable faculty characteristics of the new order." 32 The Town and Country Review, a newspaper from London, published in 1933, "Women arrive at political eminence by many and varied services to their community and their state. Of course, those who have thus arrived, none have a more honored record than Lenna Lowe Yost."33 U.S. Attorney General John C.

\footnotetext{
29 “Mrs. Yost to Play Part in Campaign,” (undated typescript), Yost Papers, Box 3.

${ }^{30}$ Nixon to Yost, 2 September, 1971, Yost Papers, Box 2.

31 Anna Steese Richardson, "Personality Sketch,” October, 1928, Yost Papers, Box 3.

${ }^{32}$ Martha Brock, “(Mrs. Ellis A.) Lenna Lowe Yost,” (undated typescript), Yost Papers, Box 3.

33 “Mrs. Ellis A. Yost from Town and Country Review," 2 October, 1933, Yost Papers, Box 3.
} 
Sargent was present at the dedication of the women's prison in Alderson. He responded with a humorous but telling quip when asked if he had passed Yost on the road from Alderson to Charleston, "Well, we passed a car containing a woman that Mr. Blank insisted was Mrs. Yost; and I said, “ If it was Mrs. Yost we wouldn't be passing her!"34

From a small village in the mountain state, this extraordinary woman set forth on an extraordinary life which saw her accomplish numerous reforms and champion countless causes with success that most can only dream of. Her achievements are an inspiration to all who seek to realize serious and challenging goals, both personal and professional. Naturally talented, Lenna Lowe Yost's passion for her state and country, her undeniable charisma, her courage of conviction, and her determination placed West Virginia among the leading states during the most ardent reforms of the Progressive Era.

\footnotetext{
34 “Special appointments,” (undated typescript), Yost Papers, Box 2.
} 


\section{Bibliography:}

Primary:

Manuscripts:

Catt, Carrie Chapman papers, 1887-1947, New York Public Library, New York, NY

Cornwell, John J papers. West Virginia Regional Collection, West Virginia University Library, Morgantown, WV

Harmer, Harvey W. papers, West Virginia and Regional Collection, West Virginia University Library, Morgantown, WV.

Kump, Herman Guy papers, West Virginia and Regional Collection, West Virginia University Library, Morgantown, WV.

Sutherland, Howard papers, West Virginia and Regional Collection, West Virginia University Library, Morgantown, WV

Yost, Lenna Lowe papers. West Virginia and Regional Collection, West Virginia University Library, Morgantown, WV.

Books:

Miller, Mrs. A.K., and Mrs. Urle Ridgway, Woman's Christian Temperance Union records, 6 March, 1918, Morgantown Woman's Christian Temperance Union (WV) collection, West Virginia and Regional Collection, West Virginia University, Morgantown, WV.

Johnson, Mrs. Ned (ed), Mountaineer Memories, 1883- 1983, West Virginia and Regional History Collection, West Virginia University, Morgantown, WV.

"The Wheeling Register and The National Liquor Dealer's Journal", The American Issue, Volume VII, West Virginia Edition (31 January, 1916), West Virginia and Regional Collection, West Virginia University, Morgantown, WV.

West Virginia Woman's Christian Temperance Union, Twenty- Eighth Year, Charleston, October 5, 6, 7, 1910, Minutes of the Convention and executive Committee, Reports of Corresponding Secretary, Treasurer, Superintendents and Organizers, and a List of Unions and Officers, (Fairmont, West Virginia: Index Print, 1910), 13, West Virginia and Regional Collection, West Virginia University, Morgantown, WV.

West Virginia Woman's Christian Temperance Union, Twenty- Eighth Year, Grafton, West VA., October 6, 7, 8, 1909, Minutes of the Convention and Executive Committee, Reports of Corresponding Secretary, Treasurer, Superintendents and Organizers, and a 
List of Unions and Officers, (Fairmont, West Virginia: Index Print, 1910), 27, West Virginia and Regional Collection, West Virginia University, Morgantown, WV.

West Virginia Acts of the Legislature, Thirty-first regular session, 1913, 96

Newspapers:

The New York Times (New York)

The Wheeling Register (West Virginia)

The Wheeling daily News (West Virginia)

Clarksburg Exponent (West Virginia)

The New Dominion (West Virginia)

Bluefield Daily Telegraph (West Virginia)

The Wheeling Daily News (West Virginia)

The West Virginian (West Virginia)

The Huntington Herald Dispatch (West Virginia)

The Clarksburg Daily Telegram (West Virginia)

The Wheeling Intelligencer (West Virginia)

The Charleston Daily Mail (West Virginia)

The Pendleton Times (West Virginia)

The Parkersburg Sentinel (West Virginia)

The Glenville Pathfinder (West Virginia)

\section{Secondary:}

Baker, Jean H. Votes for women, The Struggle For Suffrage Revisited. Oxford: University Press, 2002. 
Bordin, Ruth. Women and Temperance, The Quest for Power and Liberty, 1873-1900. New Brunswick, London: Rutgers University Press, 1981.

Bruere, Martha B. Does Prohibition Work? A Study Of the Operation of the Eighteenth Amendment made by the National Federation of Settlements, Assisted by Social Workers in Different Parts of the United States, New York and London: Harper and Brothers Publishers, 1927.

Buhle, Mari Jo and Buhle, Paul. The Concise History Of Woman Suffrage, Selections from the Classic Work of Stanton, Anthony, Gage, and Harper. Urbana, Chicago, London: University of Illinois Press, 1978.

Catt, Carrie C., and Shuler, Nettie R. Woman Suffrage and Politics; The Inner Story of the Suffrage Movement. Seattle: University of Washington Press, 1969, c1926.

Coker, Joe L. Liquor in the Land of the Lost Cause, Southern White Evangelicals and The Prohibition Movement. Kentucky: The University Press of Kentucky, 2007.

Cott, Nancy F. The Grounding Of Modern Feminism. New Haven and London: Yale University Press, 1987.

Dunnington, Geo A. History and Progress of the County of Marion, West Virginia, 1880. Fairmont, West Virginia: George A. Dunnington, Publisher, 1992.

Dubois, Ellen C. Harriot Stanton Blacth And The Winning Of Women Suffrage. New Haven and London: Yale University Press, 1997.

Dubois, Ellen C and Dumenil, Lynn. Through Woman's Eyes: An American History With Documents. Boston, MA: Bedford; New York: St. Martin's, 2005.

Dye, Nancy S. As Equals \& As Sisters, Feminism, Unionism, And The Women's Trade Union League Of New York. Columbia and London: University of Missouri Press, 1980.

Edwards, Rebecca. Angels in the Machinery, Gender in American Party Politics from the Civil War to the Progressive Era. New York: Oxford University Press, 1997.

Effland, Anne W. "The Woman Suffrage Movement in West Virginia, 1867-1920," (MA Thesis, West Virginia University, 1983).

Flanagan, Maureen A. America Reformed, Progressives And Progressivisms. 18901920s. New York and Oxford: Oxford University Press, 2007.

Frankel, Noralee and Dye, Nancy. S. Gender, Class, Race And Reform in The Progressive Era. Lexington, Kentucky: University Press of Kentucky, 1991. 
Graham, Sarah H. Women Suffrage and the new democracy. New Haven: Yale University Press, 1996.

Gifford, Carolyn De Swarte and Slagell, Amy R. Let Something Good be said, Speeches and Writing of Frances E. Willard. Urbana and Chicago: University of Illinois Press, 2007.

Hamm, Richard F. Shaping the Eighteenth Amendment, Temperance and Reform, Legal Culture, And the Polity, 1880-1920. Chapel Hill and London: The University of North Carolina Press, 1995.

Harper, Ida H. The History Of Woman Suffrage, Volume VI 1900-1920. New York: J.J. Little and Ives Company, 1922.

Hunter, Tera W. To Joy My Freedom, Southern Black Women's Lives and Labors After the Civil War. Cambridge, MA, and London, England: Harvard University Press, 1997.

Irwin, Inez H. The Story Of Alice Paul, And The National Women's Party. Virginia: Denlinger's Publishers, LTD., 1964.

Kirk, John W. Progressive West Virginians. Wheeling, West Virginia: Wheeling Intelligencer, 1923.

Kraditor, Aillen S. The Ideas of the Woman Suffrage Movement, 1890-19020. New York and London: W.W. Norton \& Company, 1981.

Lockard, E. Kidd “The Temperance Movement in West Virginia.” MA Thesis, West Virginia University, 1937.

McBride, Genevieve G. On Wisconsin Women, Working for Their Rights from Settlement to Suffrage. Madison, Wisconsin: The University of Wisconsin Press, 1993.

Mead, Rebecca J. How The Vote Was Won, Woman Suffrage in the Western United States, 1868- 1914. New York and London: New York University Press, 2004.

Marion County Historical Society. A History of Marion County, West Virginia, 1985. Fairmont, W.Va.: Marion County Historical Society, 1986.

Pegram, Thomas R. Battling Demon Rum, The Struggle for a Dry America, 1800-1933. Chicago: Ivan R. Dee, 1998.

Richardson, Angelique Women Who Did, Stories by Men and Women, 1890- 1914. London, England: Penguin Books Ltd., 2002. 
Rielselbach, Leroy N. Congressional Politics, The Evolving Legislative System. Bolder: West view Press, 1995.

Sklar, Kathryn Kish. Florence Kelley \& the Nation's Work, The Rise of Women's Political Culture, 1830- 1900. New Haven and London: Yale University Press, 1995.

Sterns, Peter N. Gender in World History. London and New York: Routledge, 2000.

Stuhler, Barbara. Gentle Warriors, Clara Ueland and the Minnesota Struggle for Woman Suffrage. St. Paul, Minnesota: Minnesota Historical Society Press, 1995.

Thornton, Mark. The Economics of Prohibition. Salt Lake City, Utah: University of Utah Press, 1991.

Timberlake, James H. Prohibition and the Prohibition Movement, 1900- 1920. Cambridge, Massachusetts: Harvard University Press, 1963.

Wheeler, Marjorie S. One Woman, One Vote, Rediscovering the Woman Suffrage Movement. Troutdale, Oregon: New Sage Press, 1995.

Wheeler, Marjorie S. New Women of the New South, The Leaders of the Woman Suffrage Movement in the Southern States. New York and Oxford: Oxford University Press, 1993.

"Fielding Yost, another son of Marion County, excelled with Wolverines," http://www.dailymail.com/Sports/200712180207.

Newsletters:

Baldwin, Sarah, "Lenna Lowe Yost Archives Chronicle the Woman Suffrage Movement in State and Nation," West Virginia and Regional Collection Newsletter, Volume 19, No. 1, 2003, West Virginia and Regional Collection, West Virginia University, Morgantown, WV. 